Prepared in cooperation with Monroe County Department of Health

\title{
Water Resources of Monroe County, New York, Water Years 2003-08: Streamflow, Constituent Loads, and Trends in Water Quality
}

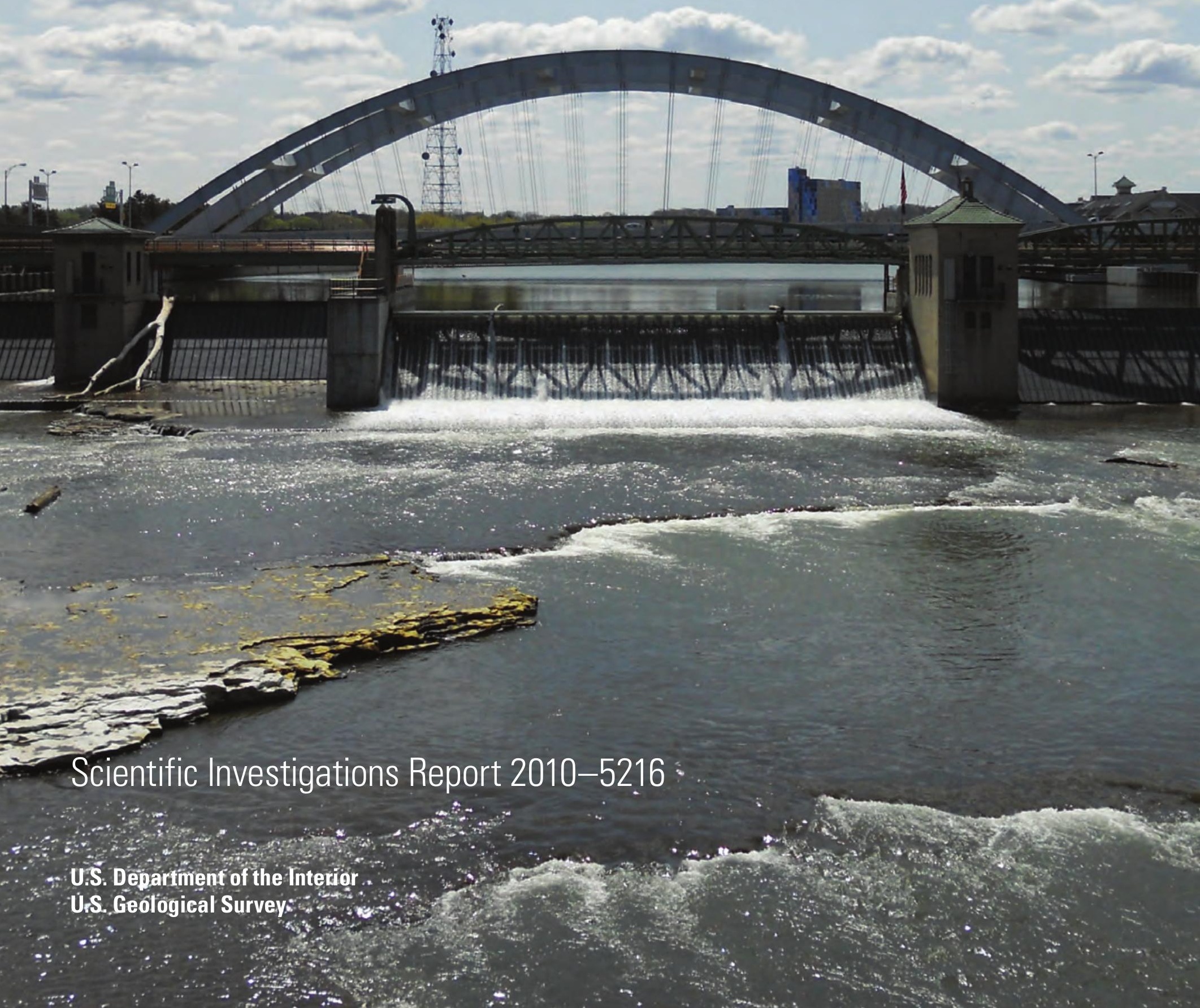


Cover. Photograph of flow-control structure on Genesee River downstream from Interstate 490 suspension bridge, Rochester, N.Y. 


\section{Water Resources of Monroe County, New York, Water Years 2003-08: Streamflow, Constituent Loads, and Trends in Water Quality}

By Brett A. Hayhurst, William F. Coon, and David A.V. Eckhardt

Prepared in cooperation with Monroe County Department of Health

Scientific Investigations Report 2010-5216 


\title{
U.S. Department of the Interior \\ KEN SALAZAR, Secretary \\ U.S. Geological Survey \\ Marcia K. McNutt, Director
}

\section{U.S. Geological Survey, Reston, Virginia: 2010}

\author{
For more information on the USGS — the Federal source for science about the Earth, its natural and living resources, \\ natural hazards, and the environment, visit http://www.usgs.gov or call 1-888-ASK-USGS \\ For an overview of USGS information products, including maps, imagery, and publications, \\ visit http://www.usgs.gov/pubprod \\ To order this and other USGS information products, visit http://store.usgs.gov
} Any use of trade, product, or firm names is for descriptive purposes only and does not imply endorsement by the
U.S. Government.
Although this report is in the public domain, permission must be secured from the individual copyright owners to
reproduce any copyrighted materials contained within this report.

Suggested citation:

Hayhurst, B.A., Coon, W.F., and Eckhardt, D.A., 2010, Water resources of Monroe County, New York, water years 2003-08: Streamflow, constituent loads, and trends in water quality: U.S. Geological Survey Scientific Investigations Report 2010-5216, 34 p., also available at http://pubs.usgs.gov/sir/2010/5216. 


\section{Acknowledgments}

Special thanks are extended to the personnel of Monroe County Environmental Laboratory for assistance in the collection, analysis, and verification of the data presented herein, and in particular to Mr. Charles Knauf, Environmental Health Project Analyst of the Monroe County Department of Health. 
This page has been left blank intentionally. 


\section{Contents}

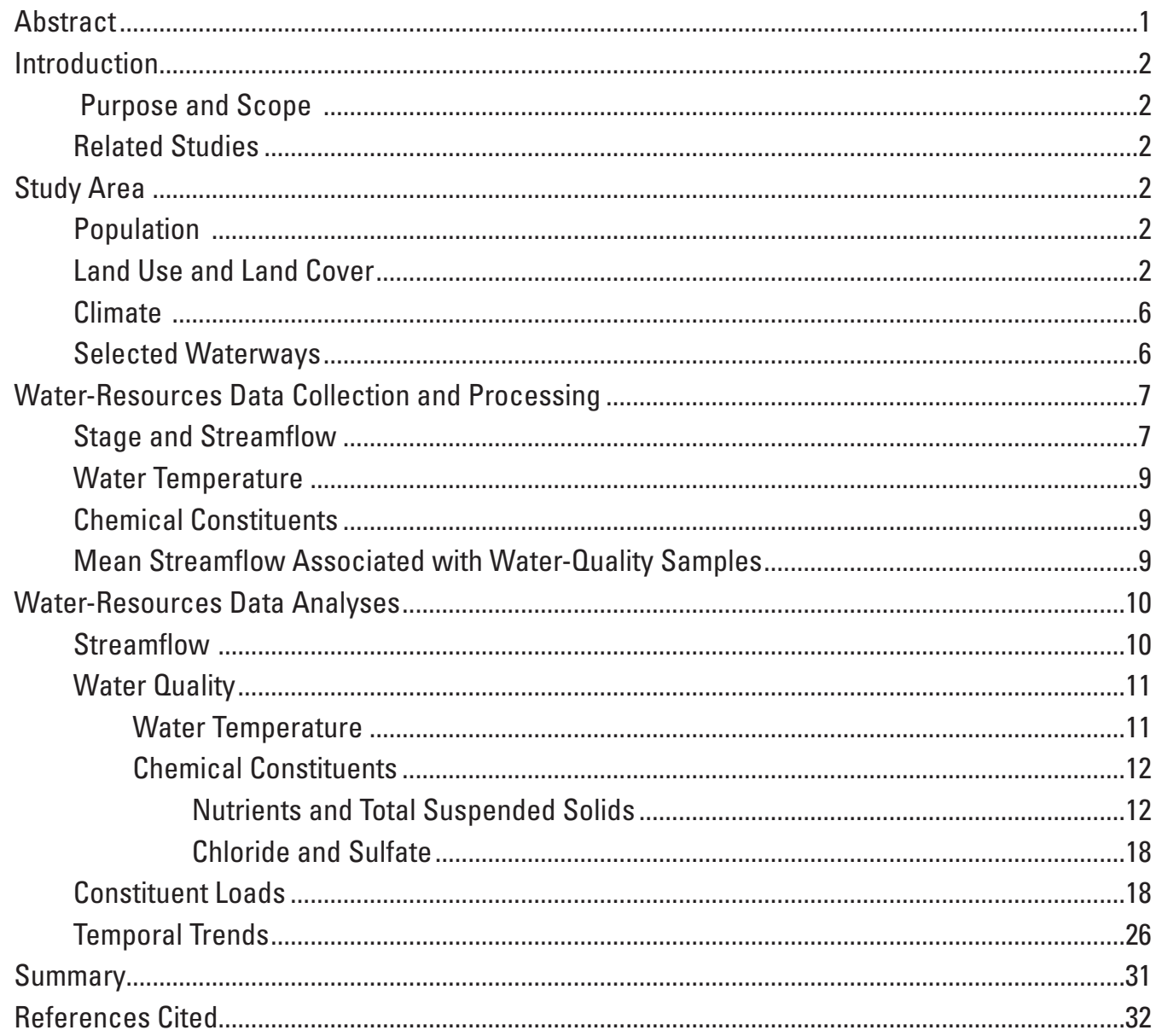

\section{Figures}

1. Map showing locations of streamflow and water-quality monitoring sites in Monroe County, N.Y.

2. Map showing locations of drainage basins of streamflow and water-quality monitoring sites in Monroe County, N.Y.

3. Graph showing population of Monroe County, N.Y., 1900-2008......................................6

4. Diagram showing precipitation at Rochester, N.Y.: A, monthly measured (2003-08) and normal (1971-2000) precipitation; and B, monthly mean, maximum, and minimum (2003-08) and normal (1971-2000) precipitation.

5. Graph showing mean annual streamflow yields at nine monitoring sites in Monroe County, N.Y., water years 2003-08.

6. Graph showing mean monthly water temperatures at four monitoring sites in Monroe County, N.Y., water years 2003-08 
7. Graph showing annual yields of selected constituents at nine monitoring sites in Monroe County, N.Y., water years 2003-08: A, chloride; B, sulfate; C, nitrate plus nitrite nitrogen; $D$, ammonia plus organic nitrogen; and $E$, phosphorus

8. Diagram showing seasonal variation in constituent concentration at selected sites in Monroe County, N.Y., water years 2003-08: A, chloride, Allen Creek near Rochester; B, nitrate plus nitrite nitrogen, Oatka Creek at Garbutt; and C, phosphorus, Genesee River at Charlotte Pump Station near Rochester..

9. Diagram showing seasonal variation in monthly constituent loads at selected sites in Monroe County, N.Y., water years 2003-08: A, chloride, Allen Creek near Rochester; B, nitrate plus nitrite nitrogen, Oatka Creek at Garbutt; and C, phosphorus, Genesee River at Charlotte Pump Station near Rochester

\section{Tables}

1. Streamflow and water-quality monitoring sites in Monroe County, N.Y., water years 2003-08.

2. Land uses and land covers in Monroe County, N.Y...

3. Median constituent concentrations by water year and summary statistics for concentrations of selected constituents in water samples from nine monitoring sites in Monroe County, N.Y., water years 2003-08

4. Estimated annual constituent loads at nine monitoring sites in Monroe County, N.Y., water years 2003-08, and statistically significant model variables.

5. Annual yields of selected constituents at nine monitoring sites in Monroe County, N.Y., water years 2003-08..

6. Trends in concentrations of selected constituents at nine monitoring sites in Monroe County, N.Y., water years 2003-08. 


\section{Conversion Factors and Abbreviations}

\begin{tabular}{lcl}
\hline Multiply & By & To obtain \\
\hline & Length & \\
\hline inch (in.) & 25.4 & millimeter $(\mathrm{mm})$ \\
foot (ft) & 0.3048 & meter $(\mathrm{m})$ \\
mile (mi) & 1.609 & kilometer $(\mathrm{km})$ \\
\hline & Area & \\
\hline acre & 4,047 & square meter $\left(\mathrm{m}^{2}\right)$ \\
square mile $\left(\mathrm{mi}^{2}\right)$ & 2.590 & square kilometer $\left(\mathrm{km}^{2}\right)$ \\
\hline & Volume & \\
\hline cubic foot $\left(\mathrm{ft}^{3}\right)$ & 0.02832 & cubic meter $\left(\mathrm{m}^{3}\right)$ \\
\hline & Flow rate & \\
\hline cubic foot per second $(\mathrm{ft} / \mathrm{s})$ & 0.02832 & cubic meter $\mathrm{per} \mathrm{second}\left(\mathrm{m}^{3} / \mathrm{s}\right)$ \\
cubic foot per second per square & 0.01093 & cubic meter per second per square \\
mile $\left[\left(\mathrm{ft}^{3} / \mathrm{s}\right) / \mathrm{mi}^{2}\right]$ & & kilometer $\left[\left(\mathrm{m}^{3} / \mathrm{s}\right) / \mathrm{km}^{2}\right]$ \\
gallon per minute $($ gal $/ \mathrm{min})$ & 0.06309 & liter per second $(\mathrm{L} / \mathrm{s})$ \\
million gallons per day $(\mathrm{Mgal} / \mathrm{d})$ & 0.04381 & cubic meter per second $\left(\mathrm{m}^{3} / \mathrm{s}\right)$ \\
\hline & Mass & \\
\hline pound, avoirdupois $(\mathrm{lb})$ & 0.4536 & kilogram $(\mathrm{kg})$ \\
ton, short $(2,000 \mathrm{lb})$ & 0.9072 & megagram $(\mathrm{Mg})$ \\
ton per day per square mile & 0.3503 & megagram per day per square \\
{$\left[(\right.$ ton $\left./ \mathrm{d}) / \mathrm{mi}^{2}\right]$} & & kilometer $\left[(\mathrm{Mg} / \mathrm{d}) / \mathrm{km}^{2}\right]$ \\
\hline
\end{tabular}

Temperature in degrees Fahrenheit $\left({ }^{\circ} \mathrm{F}\right)$ may be converted to degrees Celsius $\left({ }^{\circ} \mathrm{C}\right)$ as follows:

$$
{ }^{\circ} \mathrm{C}=\left({ }^{\circ} \mathrm{F}-32\right) / 1.8
$$

Concentrations of chemical constituents in water are given either in milligrams per liter ( $\mathrm{mg} / \mathrm{L})$ or micrograms per liter $(\mu \mathrm{g} / \mathrm{L})$.

Vertical coordinate information is referenced to the North American Vertical Datum of 1988 (NAVD 88).

Horizontal coordinate information is referenced to the North American Datum of 1983 (NAD 83).

List of Acronyms

MCEL Monroe County Environmental Laboratory

NLCD National Land Cover Data

NURP Nationwide Urban Runoff Program

NYS New York State

USGS U.S. Geological Survey 
This page has been left blank intentionally. 


\title{
Water Resources of Monroe County, New York, Water Years, 2003-08: Streamflow, Constituent Loads, and Trends in Water Quality
}

\author{
By Brett A. Hayhurst, William F. Coon, and David A.V. Eckhardt
}

\begin{abstract}
This report, the sixth in a series published since 1994, presents analyses of hydrologic data in Monroe County for the period October 2002 through September 2008. Streamflows and water quality were monitored at nine sites by the Monroe County Department of Health and the U.S. Geological Survey. Streamflow yields (flow per unit area) were highest in Northrup Creek, which had sustained flows from year-round inflow from the village of Spencerport wastewater-treatment plant and seasonal releases from the New York State Erie (Barge) Canal. Genesee River streamflow yields also were high, at least in part, as a result of higher rainfall and lower evapotranspiration rates in the upper part of the Genesee River Basin than in the other study basins. The lowest streamflow yields were measured in Honeoye Creek, which reflected a decrease in flows due to the withdrawals from Hemlock and Canadice Lakes for the city of Rochester water supply.

Water samples collected at nine monitoring sites were analyzed for nutrients, chloride, sulfate, and total suspended solids. The loads of constituents, which were computed from the concentration data and the daily flows recorded at each of the monitoring sites, are estimates of the mass of the constituents that was transported in the streamflow. Annual yields (loads per unit area) also were computed to assess differences in constituent transport among the study basins. All urban sites-Allen Creek and the two downstream sites on Irondequoit Creek - had seasonally high concentrations and annual yields of chloride. Chloride loads are attributed to the application of road-deicing salts to the county's roadways and are related to population and road densities. The lessurbanized sites in the study-Genesee River, Honeoye Creek, and Oatka Creek - had relatively low concentrations and yields of chloride. The highest concentrations and yields of sulfate were measured in Black Creek, Oatka Creek, and Irondequoit Creek at Railroad Mills and are attributable to dissolution of sulfate from gypsum (calcium sulfate) deposits in Silurian shale bedrock that crops out upstream from these monitoring sites.
\end{abstract}

Northrup Creek had the highest concentrations of phosphorus, orthophosphate, and nitrogen, and high yields of nitrate plus nitrite nitrogen and ammonia plus organic nitrogen. These results are attributed to discharges from the Spencerport wastewater-treatment plant (which ceased operation in June 2008), diversions from the New York State Erie (Barge) Canal, and manure and fertilizers applied to agricultural fields. Concentrations and yields of nitrate plus nitrite nitrogen also were high in Oatka Creek and Black Creek; basins with substantial agricultural land uses. Allen Creek had the second highest yield of ammonia plus organic nitrogen. Honeoye Creek, which drains a relatively undeveloped basin, had the lowest yields of nitrogen constituents. The second highest median concentrations and highest sample concentrations of phosphorus and orthophosphate, as well as the highest phosphorus yields, were measured in the Genesee River.

A comparison of the yields computed for the two downstream sites on Irondequoit Creek-above Blossom Road and at Empire Boulevard - permitted an assessment of the mitigative effects of the Ellison Park wetland on constituent loads, which would otherwise be transported to Irondequoit Bay. These effects also include those provided by a flow-control structure (installed mid-way through the wetland during February 1997), which was designed to increase the dispersal and short-term detention of stormflows in the wetland. The wetland decreased yields of particulate constituents - phosphorus and ammonia plus organic nitrogen - but had little effect on the yields of dissolved constituents - chloride, sulfate, and nitrate plus nitrite nitrogen.

Trends in flow-adjusted concentrations were identified at all sites for most of the nutrient constituents that were evaluated. All of the linear time trends that were detected in the data indicated that nutrient concentrations monotonically decreased during the 6-year study period, except for phosphorus concentrations in the Genesee River, which increased. Seasonal trends also were identified at all sites for nearly every constituent that was evaluated. 


\section{Introduction}

Monroe County and the U.S. Geological Survey (USGS) have monitored and evaluated the water resources of Monroe County since 1904 when a streamflow monitoring station was established on the Genesee River at Rochester, N.Y. Since that time additional streamflow monitoring sites have been established on various streams in the county, and waterquality monitoring also has been conducted. In addition to the Genesee River, sites at which flow and water-quality data are still collected include Honeoye, Oatka, Black, Allen, Irondequoit, and Northrup Creeks (fig. 1). The periods of streamflow records at these sites range from 19 years for Northrup Creek to 104 years for the Genesee River (table 1). The periods of water-quality records at these sites range from 10 years for Honeoye Creek to 27 years for Allen Creek. The hydrologic and water-quality information is used by water-resources managers to make decisions regarding flood hazards, drought conditions, control of streambank erosion, and mitigation of nonpoint-source pollution.

In 1993, the USGS, in cooperation with the Monroe County Department of Health, began a long-term program to evaluate and interpret hydrologic data collected at sites in Monroe County for calculation of constituent loads in streamflow and appraisal of temporal trends in the concentrations of selected constituents in streamflow and groundwater. Results of the monitoring program have been compiled in a series of reports that cover the water years (October 1 to September 30, numbered for the year in which it ends) 1984 through 2002 (Johnston and Sherwood, 1996; Sherwood, 1999; 2001; 2003; and 2005). This report is a continuation of this series and covers the 2003-08 water years.

\section{Purpose and Scope}

This report describes the hydrologic and water-quality conditions at nine surface-water monitoring sites in Monroe County during water years 2003-08. The report presents (1) the methods of data collection, processing, and analysis and the statistical methods used for trend analyses and estimation of constituent loads; (2) summaries of streamflow records, water-quality data, and trends of selected constituents in the monitored streams; and (3) an estimation of loads and a comparison of yields of selected constituents at the monitoring sites.

\section{Related Studies}

The hydrologic characteristics of the Irondequoit Creek Basin were studied extensively during 1979-81 as part of the Nationwide Urban Runoff Program (NURP) (U.S. Environmental Protection Agency, 1983; O’Brien and Gere, 1983; Zarriello and others, 1985; Kappel and others, 1986). The NURP study identified the heavily developed areas of the Irondequoit Creek Basin as the major sources of chemical loads and noted that snowmelt and spring runoff carried a disproportionate amount of the annual loads. The effects of stormwater-detention basins on the chemical quality of runoff from a small residential development were studied by Zarriello and Sherwood (1993), and the effects of detention basins on peak flows and water quality of major streams were studied by Zarriello and Surface (1989) and Zarriello (1996). The hydrology, sedimentology, biology, and waterquality processes of the Ellison Park wetland at the mouth of Irondequoit Creek were documented by Coon (1997; 2004) and Coon and others (2000).

\section{Study Area}

Monroe County encompasses $673 \mathrm{mi}^{2}$ in northwestern New York (fig. 1). Rochester, the county seat and largest city, is in the northern part of the county. Two creeks in the monitoring network, Northrup and Irondequoit Creeks, have drainage basins that are almost entirely within the boundaries of Monroe County and drain directly into Lake Ontario (fig. 2). In contrast, about 90 percent of the Genesee River drainage basin is outside Monroe County. Three streams, Oatka, Honeoye, and Black Creeks, are tributaries of the Genesee River; their confluences lie within Monroe County, but most of their respective drainage areas are south and west of the county. Although one monitoring site-Irondequoit Creek at Railroad Mills, near Fishers - is actually located in Ontario County, all nine sites are referred to as "Monroe County" sites because funds for the operation and maintenance of the stations are provided by Monroe County.

\section{Population}

The estimated population of Monroe County during 2006-08 was 732,175, a 0.4-percent decrease from the last official U.S. census during 2000 when the population was about 735,000 (U.S. Census Bureau, 2009a). The population of Monroe County increased from 1900 until 1970 (fig. 3; U.S. Census Bureau, 2009b), and although the population has remained fairly constant since 1970 , shifts in the population have occurred as people moved from the city of Rochester to the developing towns that border the city, including Henrietta, Pittsford, Perinton, Penfield, and Greece. Some rural towns, such as Mendon and Clarkson also have experienced population growth since 1990 (Sherwood, 2005).

\section{Land Use and Land Cover}

The primary land uses or land covers in Monroe County are residential, agricultural, and forested. Previous reports in this series of analyses of Monroe County hydrologic data discussed land types on the basis of land use only; that is, 


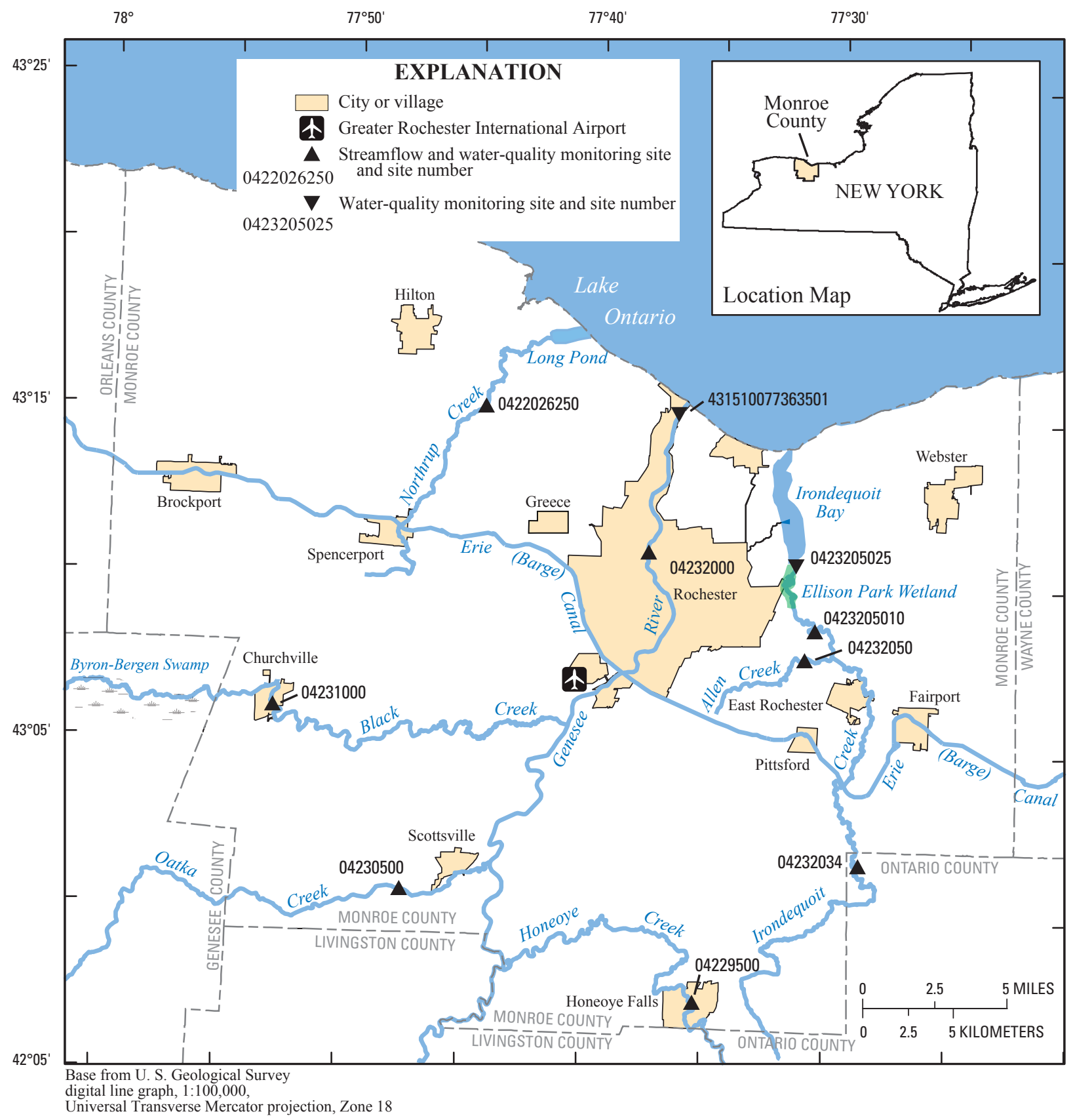

Figure 1. Locations of streamflow and water-quality monitoring sites in Monroe County, N.Y. (Site names are given in table 1.) 


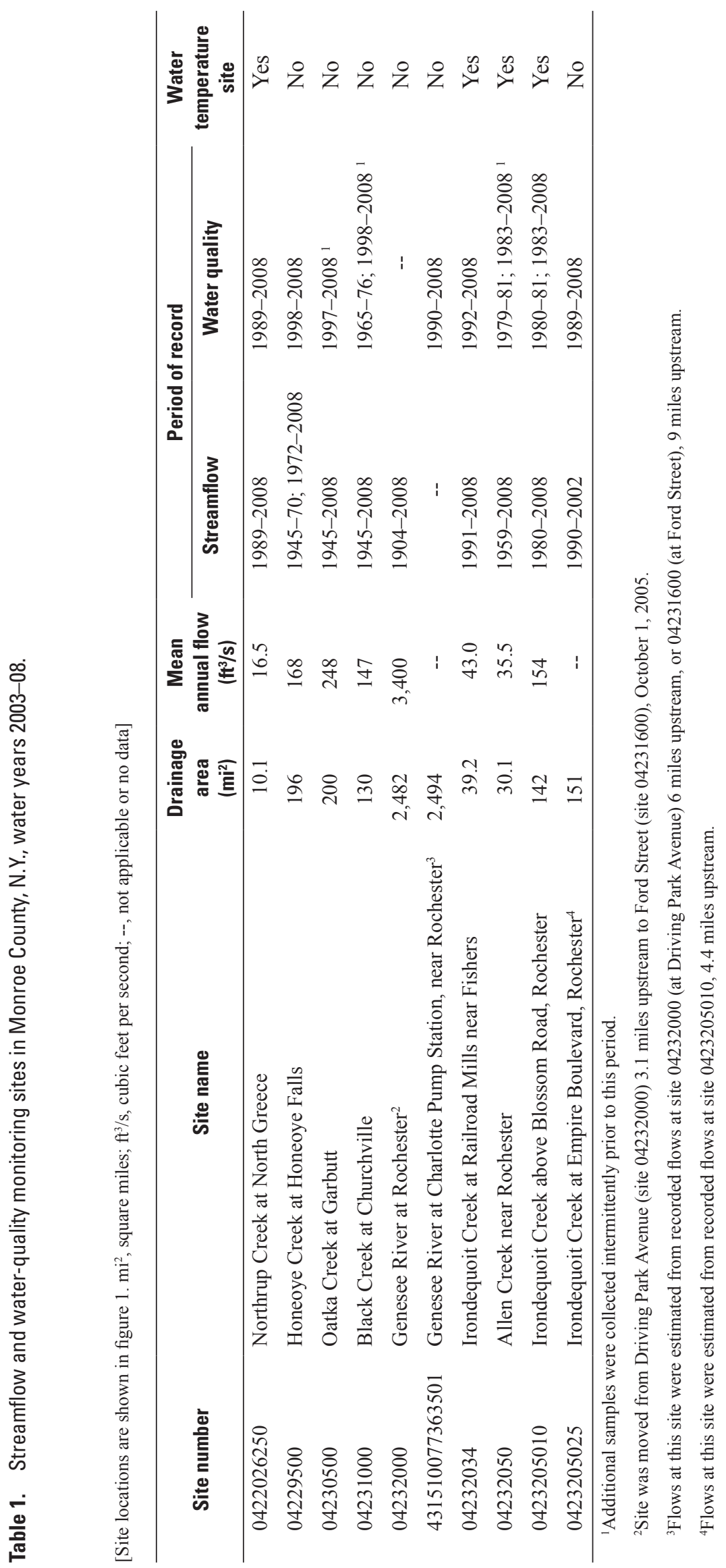




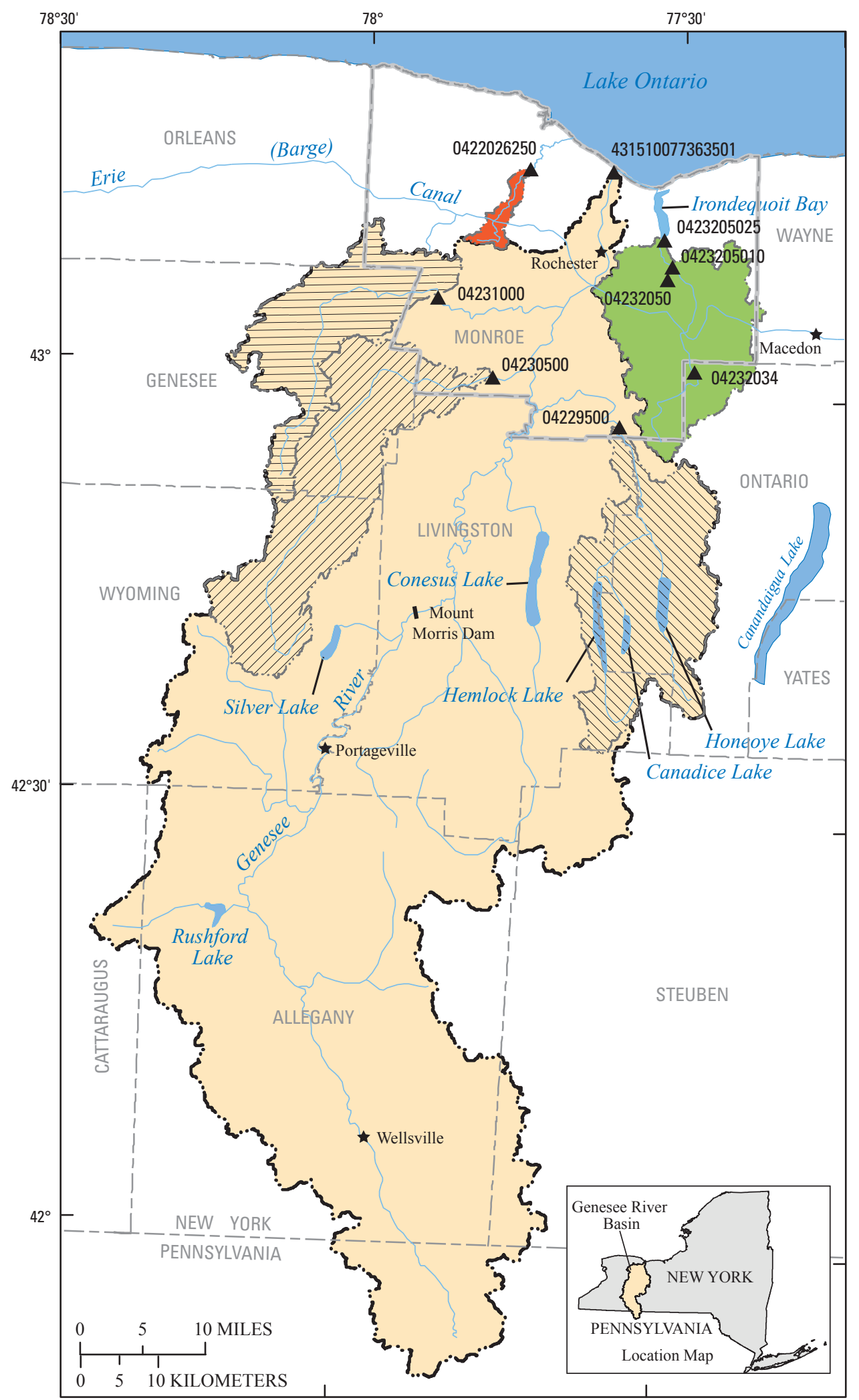

\section{EXPLANATION}

Genesee River Basin

Black Creek Basin

ZIA Oatka Creek Basin

DIV Honeoye Creek Basin

Northrup Creek Basin

Irondequoit Creek Basin

Monroe County boundary

0422026250 Streamflow and water-quality $\Delta \quad$ monitoring site and site number

Base from U. S. Geological Survey

digital line graph, 1:100,000,

Universal Transverse Mercator projection, Zone 18

Figure 2. Locations of drainage basins of streamflow and water-quality monitoring sites in Monroe County, N.Y. 


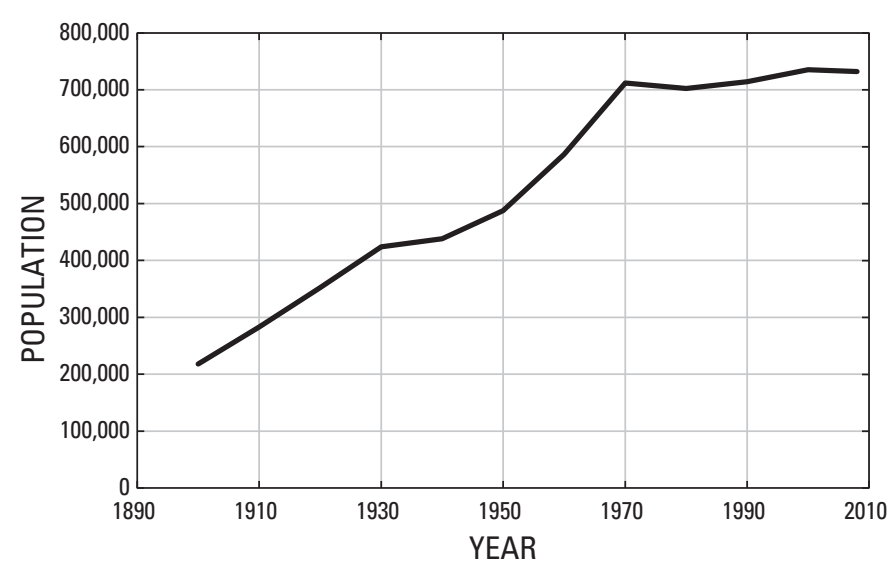

Figure 3. Population of Monroe County, N.Y., 1900-2008.

property types as classified by New York State Office of Real Property Services (2009) for tax purposes. If a land-cover based classification system, such as the National Land Cover Data (NLCD; Homer and others, 2004), is used, the relative magnitudes of land-type categories can vary substantially, however. For instance, on the basis of property-tax data, 48 and 23 percent of the county is used for developed (residential, commercial, and industrial) and agricultural purposes, respectively (table 2) (Tongyan Li, Monroe County Department of Planning and Development, written commun., 2009). Only 4 percent of the county is classified as forested, which includes conservation lands and public parks. On the basis of NLCD, 30 percent of the county was developed land in 2001, and 40 percent was agricultural land (cultivated crops, hay, and pasture). Land covered by forests in 2001 accounted for 21 percent of the county. Despite the large differences in land-type percentages, the data from both classification systems indicate a continued pattern of land conversion from agricultural uses to residential uses, as shown by Sherwood (2005) in the previous water-resources report for Monroe County. On the basis of property-tax data, since 2002 (table 2), residential land use has increased from 35.4 to 38.6 percent of the county, whereas agricultural uses have decreased from 26.1 to 22.7 percent (New York State Office of Real Property Services, 2009).

\section{Climate}

Weather data in Monroe County are collected by the National Weather Service at the Greater Rochester International Airport, which is located near the center of the county, just southwest of the city of Rochester (fig. 1). Average annual precipitation (1971-2000) in the Rochester area is 33.98 in., including an average snowfall of $95.8 \mathrm{in.} \mathrm{(National}$ Climatic Data Center, 2009a).

The weather in the county is greatly affected by Lake Ontario, which has a moderating effect on air temperatures and inhibits the extreme temperature fluctuations that are recorded further inland (National Climatic Data Center, 2009b). Monthly 30-year mean temperatures range from $23.9^{\circ} \mathrm{F}$ in January to $70.7^{\circ} \mathrm{F}$ in July (National Climatic Data Center, 2009a). Lake Ontario, which rarely freezes completely during the winter, plays a major role in snowfall distribution. Lake-effect storms can produce snowfalls of 1 to $2 \mathrm{ft}$ or more in a $24 \mathrm{hr}$ period near the lake and by season's end can account for about half the total snowfall in the area (National Climatic Data Center, 2009b). Seasonal snowfall quantities can vary widely and usually decrease with distance from the lake. Precipitation is fairly evenly distributed throughout the year; monthly 30-year mean quantities range from 2.04 in. during February to 3.54 in. during August (National Climatic Data Center, 2009a). Heavy rain events occur infrequently and generally are caused by slowly moving thunderstorms, slowly moving or stalled major low-pressure systems, or by hurricanes and tropical storms that move inland (National Climatic Data Center, 2009b).

Average annual precipitation during the 6-year study period (2003-08) was 35.27 in., more than an inch greater than the 30-year mean precipitation (1971-2000; National Climatic Data Center, 2009a). This departure from the annual normal precipitation resulted from 2 very wet years during the study period; 37.81 in. and 41.06 in. of precipitation fell during 2004 and 2006, respectively (fig. 4A). During water years 2003-08 (National Climatic Data Center, 2009c), the largest monthly departure from the normal values occurred during July with an average of 4.37 in. of precipitation. The 30 -year monthly normal precipitation for July is $2.93 \mathrm{in}$.

(fig. 4B). Precipitation totals during July 2004 (6.35 in.) and July 2006 (8.02 in.) are responsible for the large departures from that month's normal value.

\section{Selected Waterways}

The Genesee River, which flows northward from its origin in northwestern Pennsylvania to Lake Ontario at Rochester (fig. 2), is the largest river in Monroe County and has a drainage area of 2,494 $\mathrm{mi}^{2}$ at its mouth. Since 1951, the flow rates in the Genesee River have been affected by operation of the dam at Mount Morris (fig. 2), about $39 \mathrm{mi}$ upstream from Rochester. The magnitude and frequency of damaging floods have been lowered, and the regulated outflow from Mount Morris Lake has maintained base flows at slightly higher rates than those that occurred prior to the dam's construction (Coon, 2008). The Genesee River is a large source of sediment to Lake Ontario (New York State Department of Environmental Conservation, 2003). Much of the load is derived from highly erodible soils on the alluvial plain through which the river flows for most of its length. Extensive agricultural activity and continuing land development throughout the basin also contribute to sediment loads. 
Table 2. Land uses and land covers in Monroe County, N.Y.

[Values are in percent.]

\begin{tabular}{|c|c|c|c|c|}
\hline Property type $^{1}$ & 2002 & 2008 & Land use - land cover ${ }^{2}$ & 2001 \\
\hline Forested, conservation lands, and public parks & 3.72 & 4.06 & Forest & 21.2 \\
\hline \multirow[t]{2}{*}{ Agricultural } & 26.14 & 22.66 & Total Agricultural & 39.6 \\
\hline & & & Hay and pasture & 22.6 \\
\hline Vacant land & 18.70 & 18.62 & & \\
\hline Residential & 35.41 & 38.64 & Open space and low intensity & 24.6 \\
\hline Commercial & 4.41 & 4.76 & Medium intensity & 4.0 \\
\hline Industrial & 2.25 & 2.13 & High intensity & 1.5 \\
\hline \multirow[t]{2}{*}{ Recreation and entertainment } & 3.04 & 2.83 & & \\
\hline & & & Wetlands & 7.0 \\
\hline
\end{tabular}

${ }^{1}$ Data from New York State Office of Real Property Services (2009).

${ }^{2}$ Data from National Land Cover Database (Homer and others, 2004).

Honeoye Creek, Oatka Creek, and Black Creek are tributaries of the Genesee River in southwestern Monroe County (fig. 1), and the drainage areas range from $201 \mathrm{mi}^{2}$ to $267 \mathrm{mi}^{2}$. All three basins have large forested areas, but agricultural activities dominate the land uses of most of these basins. A considerable part of the Black Creek Basin is covered by wetlands, including an over 2,000-acre wetland complex, the Byron-Bergen Swamp (fig. 1; Genesee County, 2009).

East of the Genesee River, Irondequoit Creek, which drains $169 \mathrm{mi}^{2}$, flows northward into Irondequoit Bay and then into Lake Ontario. The land uses in the basin transition from forested and agricultural uses in the southern part to intensive urbanized uses in the north.

Northrup Creek drains $23.5 \mathrm{mi}^{2}$ in western Monroe County and flows into Long Pond (fig. 1), a small embayment on the southern shore of Lake Ontario. The drainage area has a mixture of land types, including forest, agriculture, and lowintensity development.

The New York State (NYS) Erie (Barge) Canal (fig. 1 and 2) flows generally eastward through the middle of the county and receives a small amount of inflow from two tributaries in the Town of Pittsford, as well as storm runoff from areas immediately adjacent to the canal in the villages of Pittsford and Fairport; a total area of $8.45 \mathrm{mi}^{2}$ drains directly to the canal in these areas. Overflow spillways and siphons divert canal water to local streams, including Allen Creek and Northrup Creek, to augment summertime low flows in these small streams. These diversions to Allen Creek were periodically measured during $2000-03$ and averaged about $3.5 \mathrm{ft}^{3} / \mathrm{s}$ from one spillway and about $2 \mathrm{ft}^{3} / \mathrm{s}$ from each of two siphons (U.S. Geological Survey, 2009a). These diversions cease during the non-navigation season (November to April) when the canal is drained. The canal intersects the Genesee River 11.8 mi upstream from the river's mouth. Water, which is diverted by the canal from the Niagara River and Tonawanda Creek to the west, discharges into and joins the Genesee River as it flows northward to Lake Ontario. A relatively small amount of water from the Genesee River enters the eastern continuation of the canal and flows eastward from this point. During the navigation season (from late April to mid-November), daily flows in the canal east of the Genesee River typically range from 200 to $300 \mathrm{ft}^{3} / \mathrm{s}$ (data from the USGS monitoring site at Lock 30 at Macedon (fig. 2); site number 04219000 (U.S. Geological Survey, 2009a)).

\section{Water-Resources Data Collection and Processing}

Water levels at the nine monitoring sites and water temperatures at four of the sites were recorded continuously during the study period. Water-quality samples were collected periodically and analyzed for nutrients, selected ions, and total suspended solids.

\section{Stage and Streamflow}

The water level or stage of the stream at each of the nine monitoring sites was measured every 15 min using standard USGS procedures (Buchanan and Somers, 1968) 

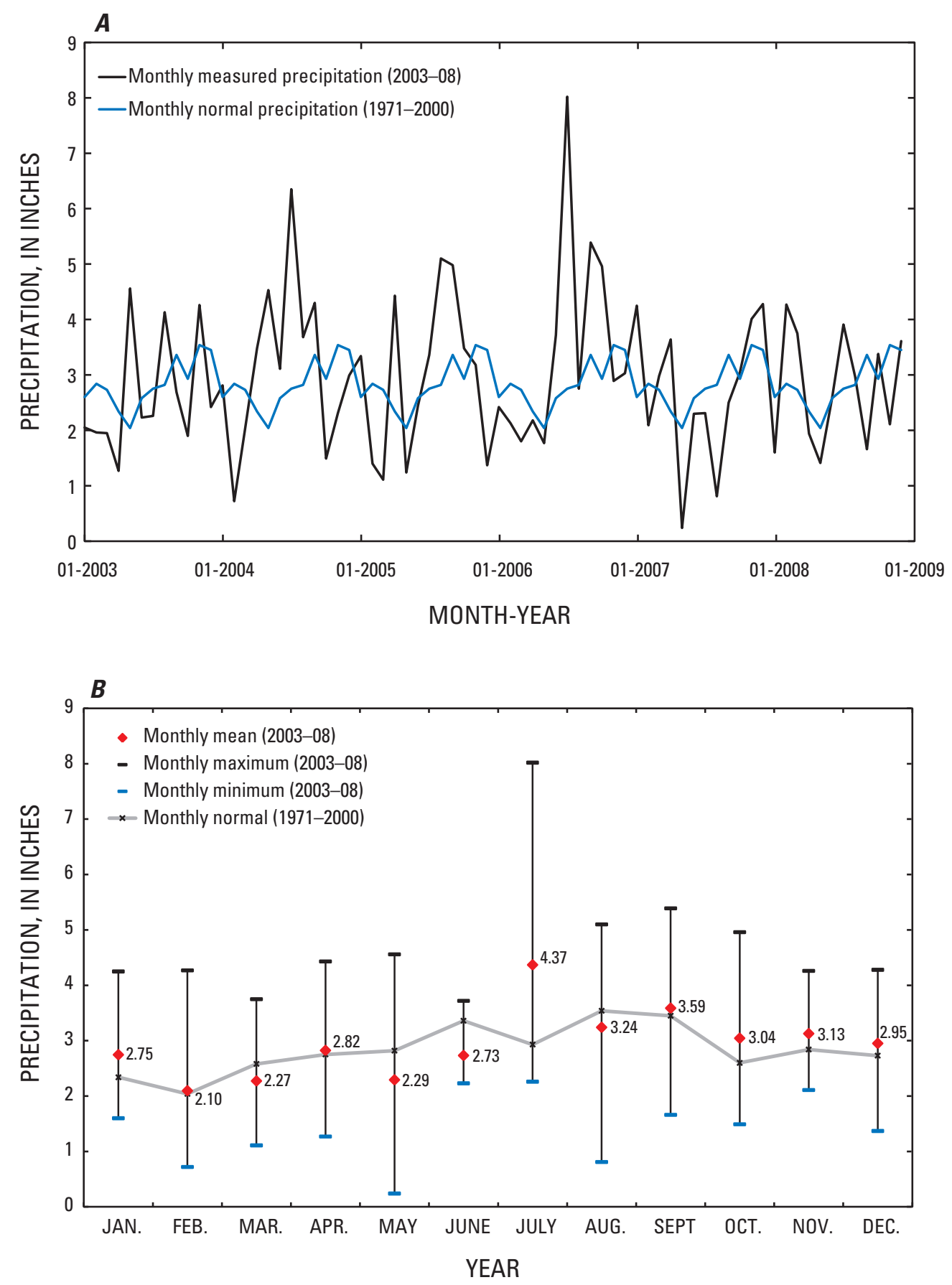

Figure 4. Precipitation at Rochester, N.Y.: A, monthly measured (2003-08) and normal (1971-2000) precipitation; and $B$, monthly mean, maximum, and minimum (2003-08) and normal (1971-2000) precipitation. (Data from the National Weather Service station at the Greater Rochester International Airport.) 
and recorded by an electronic data logger. Streamflow was measured regularly by personnel from the Monroe County Environmental Laboratory (MCEL) and periodically by personnel from the USGS, according to procedures described in Carter and Davidian (1968), Buchanan and Somers (1969), and Rantz and others (1982). Stage and streamflow data were compiled and streamflows were computed from stage-to-discharge relations that were developed through standard USGS procedures (Kennedy, 1983). Streamflows were computed by the USGS, and daily mean flows were published in the USGS annual water data reports (U.S. Geological Survey, 2009b).

\section{Water Temperature}

Water temperatures were recorded every $15 \mathrm{~min}$ by thermistors placed in well mixed locations near the bed of the channels at four monitoring sites (table 1). As quality checks on the recorded temperatures, seasonal equal-width cross-sectional measurements of temperature were made with a digital thermistor by USGS personnel. In general, corrections were made to the recorded temperatures on the basis of cross-sectional temperatures only when discrepancies of $1.0^{\circ} \mathrm{C}\left(1.8^{\circ} \mathrm{F}\right)$ or more were noted. Erroneous temperatures that were recorded during periods of thermistor malfunction were deleted from the record. Daily mean temperatures were computed and rounded to the nearest $0.5^{\circ} \mathrm{C}\left(0.9^{\circ} \mathrm{F}\right)$.

\section{Chemical Constituents}

Water samples were collected by automatic samplers at each of the nine monitoring sites. Samplers were activated during a base-flow period or in anticipation of a storm event, and water samples were extracted hourly from the channel (near the centroid of flow). Samples collected over a period of up to 7 hours were composited in a single sample bottle, which is presumed to represent water chemistry that existed in a stream during that time period. Subsequently, water samples were composited into a single sample that represented base flow or storm runoff over a period ranging from 1 to 7 days. A sample for analysis was extracted from this multiday composite sample. This method of compositing samples, which fails to flow-weight the sub-sample volumes, will likely underestimate the "true" concentrations of some constituents in stormwater samples; however, this protocol has been used since the beginning of the Monroe County stream-monitoring program and is inherent in the results presented in previous reports in this water-resources series (Johnston and Sherwood, 1996; Sherwood, 1999, 2001, 2003, and 2005). Samples were collected from the field and processed by personnel from MCEL. The frequency of sampling varied year-to-year with more than 60 samples collected at Genesee River at Charlotte Pump Station during 2003 and as few as three samples collected at some sites during 2006.
Samples were analyzed for phosphorus, orthophosphate, ammonia, nitrate plus nitrite nitrogen, ammonia plus organic nitrogen, chloride, sulfate, and total suspended solids in the MCEL. Analytical procedures used by MCEL are described by American Public Health Association and others (2010). Results of the water-quality analyses are stored in the USGS National Water Information System (U.S. Geological Survey, 2009a). The MCEL participated in the semiannual USGS quality-assurance Standard Reference Sample program (U.S. Geological Survey, 2009c) that is coordinated by the USGS Office of Water Quality for cooperating analytical laboratories. The results from this program indicated that the MCEL performed well in the analyses of constituents measured as part of the Monroe County water-quality monitoring program. No problem in analytical techniques was identified.

\section{Mean Streamflow Associated with Water-Quality Samples}

The mean streamflow that was associated with the time period covered by the water-quality samples was computed from the continuous streamflow recorded at each monitoring site, except at Genesee River at Charlotte Pump Station and Irondequoit Creek at Empire Boulevard. Streamflow was not measured at the Genesee River at Charlotte Pump Station; rather streamflow values associated with these samples were obtained from records for the Genesee River at Rochester, which was measured upstream from Driving Park Avenue (site 04232000) until September 30, 2005, and at Ford Street (site 04231600 ) after that date. Although the Ford Street site is about $3.1 \mathrm{mi}$ upstream from the Driving Park Avenue site, the streamflow records at both sites are considered equivalent owing to the small difference in drainage area $\left(8 \mathrm{mi}^{2}\right.$ or 0.3 percent) between the sites and to the fact that the stormwater drainage system for most of Rochester routes water to an underground storage area for eventual treatment at a regional wastewater-treatment facility and discharge to Lake Ontario (C. Knauf, Monroe County Department of Health, written commun., 2010). Similarly, and for the same reasons, measured streamflows were used without adjustment as flow estimates for the water-quality site at Charlotte Pump Station, which is at least $6 \mathrm{mi}$ downstream from the streamflowmonitoring sites (a difference in drainage area of $12-20 \mathrm{mi}^{2}$ or $0.5-0.8$ percent).

Streamflows in Irondequoit Creek at Empire Boulevard have not been measured since December 2002. Therefore streamflows at this site were estimated from the measured flows at Irondequoit Creek at Blossom Road, 4.4 mi upstream. This estimation was performed by a regression equation that was developed from daily streamflows that were concurrently measured at Blossom Road and Empire Boulevard during the 1997-2001 water years. 


\section{Water-Resources Data Analyses}

Mean annual flows at the nine monitoring sites were computed and then normalized by their respective drainagebasin areas to account for differences in drainage-area size, which permitted direct comparison of streamflow yields (flow per square mile) among the nine sites. Differences in yields among the sites could result from streamflow diversions, such as are found in Northrup Creek, Allen Creek, and Honeoye Creek, or from variability in precipitation and evapotranspiration across a large basin. The Genesee River, for example, drains an area near the New York-Pennsylvania border where the mean annual precipitation is $32 \mathrm{in}$., and the mean annual runoff is 14 in. (Randall, 1996). Basins further north, which are closer to or within Monroe County, drain an area where the mean annual precipitation is 30 in., and the mean annual runoff is 12 in.

Water temperatures and constituent-concentration data were summarized for the study period. The loads and yields of constituents were computed from streamflow and concentration records, and trends in constituent concentrations were identified, where possible.

\section{Streamflow}

Northrup Creek at North Greece, which drains the smallest basin in the Monroe County network (10.1 mi²), had sustained flows and the highest streamflow yield (fig. 5) of all the monitoring sites. The site's hydrology is affected by year-round discharges from the village of Spencerport (fig. 1) wastewater-treatment plant (discontinued after June 2008) and seasonal releases from the NYS Erie (Barge) Canal; both water sources are about 5.4 mi upstream from the monitoring site. The wastewater-treatment plant discharged, on average (1991-2003), 0.9 Mgal/d (1.39 ft³/s) (Craig Jackson, New York State Department of Environmental Conservation, written commun., 2010), and the releases from the canal were, on average (2001-03), about $5 \mathrm{ft}^{3} / \mathrm{s}$ (U.S. Geological Survey, 2009a). The mean annual flow in Northrup Creek at North Greece for the 2003-08 water years was $16.5 \mathrm{ft}^{3} / \mathrm{s}$, and the mean annual streamflow yield was $1.63\left(\mathrm{ft}^{3} / \mathrm{s}\right) / \mathrm{mi}^{2}$.

Honeoye Creek at Honeoye Falls drains an area of $196 \mathrm{mi}^{2}$, which includes Honeoye, Hemlock, and Canadice Lakes (fig. 2). Honeoye Lake is unregulated, but flow from Canadice Lake is diverted to Hemlock Lake, which supplies an average of $37 \mathrm{Mgal} / \mathrm{d}\left(57 \mathrm{ft}^{3} / \mathrm{s}\right)$ to the city of Rochester. Spillage over the dam at the north end of Hemlock Lake occurs infrequently (mainly during spring high-runoff periods); otherwise, the lake does not contribute flows to Honeoye Creek (Donald Root, City of Rochester Water Supply, written commun., 2009). Honeoye Creek had a mean annual flow of $169 \mathrm{ft}^{3} / \mathrm{s}$ and a mean annual streamflow yield of $0.86\left(\mathrm{ft}^{3} / \mathrm{s}\right) / \mathrm{mi}^{2}$ for the $2003-08$ water years. This yield was the lowest mean annual yield (fig. 5) of all the monitoring sites due to the withdrawals from Hemlock Lake; otherwise the yield, adjusted for the water-supply diversion to Rochester, would have been $1.15\left(\mathrm{ft}^{3} / \mathrm{s}\right) / \mathrm{mi}^{2}$.

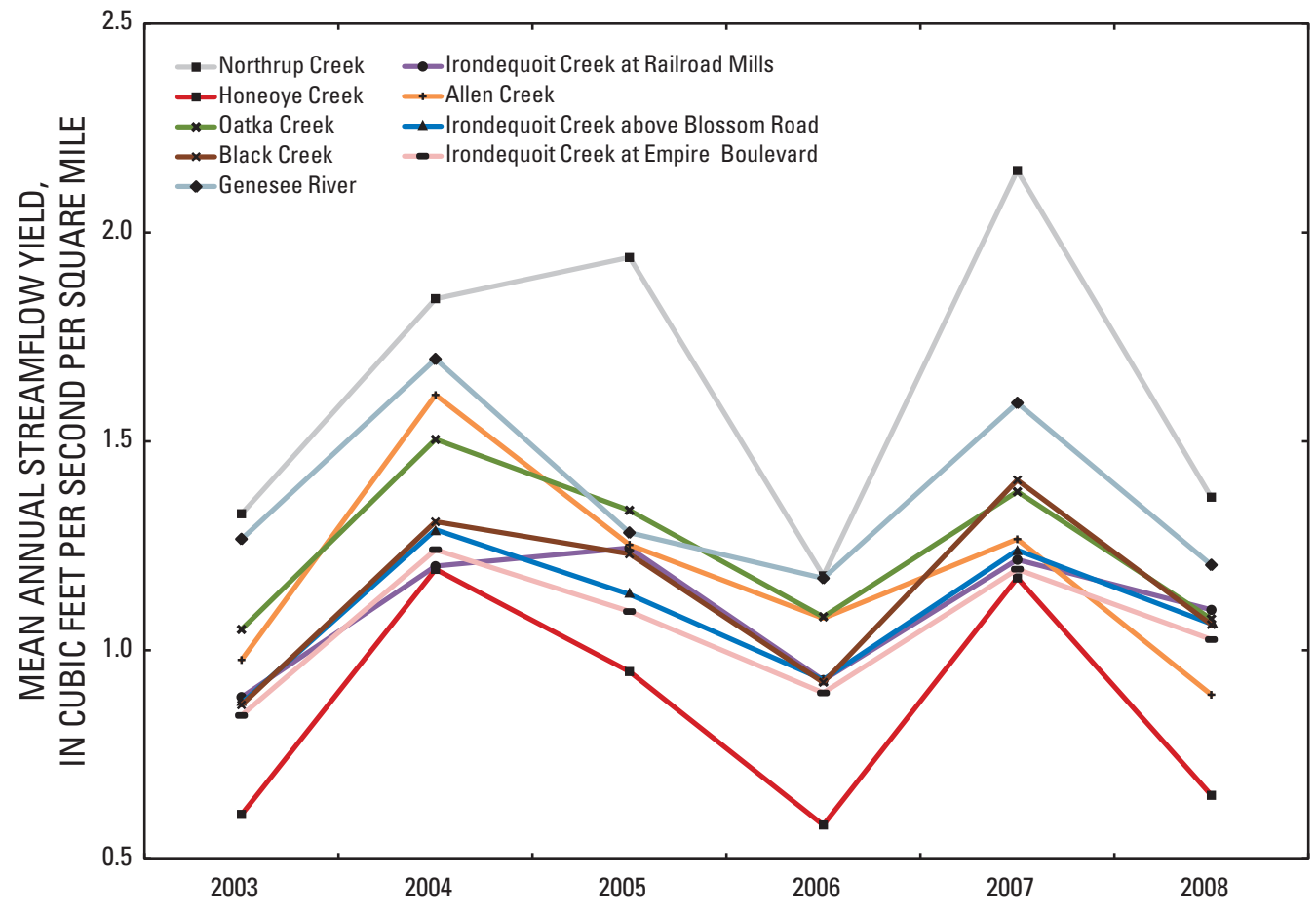

Figure 5. Mean annual streamflow yields at nine monitoring sites in Monroe County, N.Y., water years 2003-08. 
Oatka Creek at Garbutt, with a drainage area of $200 \mathrm{mi}^{2}$, had a mean annual flow for the 2003-08 water years of $248 \mathrm{ft}^{3} / \mathrm{s}$ and a mean annual yield of $1.24\left(\mathrm{ft}^{3} / \mathrm{s}\right) / \mathrm{mi}^{2}$. Black Creek at Churchville, which has a drainage area of $130 \mathrm{mi}^{2}$, had a mean annual flow of $147 \mathrm{ft}^{3} / \mathrm{s}$ and a mean annual yield of $1.13\left(\mathrm{ft}^{3} / \mathrm{s}\right) / \mathrm{mi}^{2}$.

The mean annual flow in Genesee River at Rochester for the 2003-08 water years was $3,400 \mathrm{ft}^{3} / \mathrm{s}$, a mean annual yield of $1.37\left(\mathrm{ft}^{3} / \mathrm{s}\right) / \mathrm{mi}^{2}$. The combined streamflows from the three tributaries - Honeoye, Oatka, and Black Creeksaccounted for about 17 percent $\left(564 \mathrm{ft}^{3} / \mathrm{s}\right)$ of the total mean annual flow in the Genesee River at Rochester. The streamflow yield of the Genesee River was the second highest yield of all the monitoring sites (fig. 5) and is attributed, in part, to the relatively high yields from the upper part of the Genesee River Basin, which has higher elevations, more precipitation, and less evapotranspiration than most of the area drained by the other study basins (Gilbert and Kammerer, 1971; Randall, 1996). This conclusion is supported by the high mean annual streamflow yields of 1.63 and $1.67\left(\mathrm{ft}^{3} / \mathrm{s}\right) / \mathrm{mi}^{2}$ that were computed for the 2003-08 water years for two monitoring sites located in the upper part of the Genesee River Basin - the Genesee River at Wellsville and at Portageville, respectively (fig. 2).

Four of the nine monitoring sites in Monroe County are in the Irondequoit Creek Basin; three of these sites - one on Allen Creek and two on Irondequoit Creek (fig. 1) - measure streamflows. The site on Irondequoit Creek at Railroad Mills monitors flows from $39.2 \mathrm{mi}^{2}$ of mixed land uses that include forests, pasture, cultivated crops, and some residential and commercial areas. The mean annual flow for the 2003-08 water years was $43 \mathrm{ft}^{3} / \mathrm{s}$ with a mean annual yield of $1.10\left(\mathrm{ft}^{3} / \mathrm{s}\right) / \mathrm{mi}^{2}$. Suburban development increases northward across the Irondequoit Creek Basin. Allen Creek drains $30.1 \mathrm{mi}^{2}$ of land that is dominated by moderate- to high-intensity residential and commercial uses. The hydrology of this basin is not representative of most of the Irondequoit Creek Basin because peak flows in Allen Creek generally are characterized by quick runoff from impervious surfaces in the basin. Diversions from the NYS Erie (Barge) Canal occur during the navigation season (late April to mid-November) to augment summer low flows in Allen Creek. Summer diurnal fluctuations in streamflow are common as water is withdrawn from the creek and its tributary, East Branch Allen Creek, to irrigate golf courses. The mean annual flow for the 2003-08 water years was $36 \mathrm{ft}^{3} / \mathrm{s}$ with a mean annual yield of 1.18 $\left(\mathrm{ft}^{3} / \mathrm{s}\right) / \mathrm{mi}^{2}$. The northern part of the Irondequoit Creek Basin is highly developed. The collective effects of this urbanization are monitored at the Blossom Road site, near Rochester. The drainage area of Irondequoit Creek above Blossom Road is $142 \mathrm{mi}^{2}$, and mean annual flow for the 2003-08 water years was $155 \mathrm{ft}^{3} / \mathrm{s}$ with a mean annual yield of $1.09\left(\mathrm{ft}^{3} / \mathrm{s}\right) / \mathrm{mi}^{2}$.

\section{Water Quality}

Measurements of physical characteristics, such as water temperature, and chemical constituents, such as nutrients and common ions, can be used to assess water quality. Concentrations and estimated loads of constituents in streams can highlight differences in water quality from basin to basin and, through trend analysis, can indicate whether water-quality conditions are improving or deteriorating in a given stream over time.

\section{Water Temperature}

Water temperature affects many aspects of water quality, such as the solubility of constituents (including dissolved oxygen concentrations), the rate of chemical reactions, the level of activity of organisms in the aquatic environment, and the growth and death rates of microorganisms. Water temperatures, in turn, are affected by several factors, including groundwater contributions, precipitation and storm runoff, the amount of solar radiation reaching the stream, and the temperature of tributary inflows.

Temperature records have been kept for Northrup Creek at North Greece and three of the four monitoring sites in the Irondequoit Creek Basin since 1994. Mean monthly water temperatures during water years 2003-08 (fig. 6) ranged from $33^{\circ} \mathrm{F}$ in February to $72^{\circ} \mathrm{F}$ in July; both extremes were recorded at Northrup Creek. Of the three sites on Irondequoit Creek, the upstream-most site at Railroad Mills had the coolest year-round temperatures. Water temperatures were generally warmer in Allen Creek than at Railroad Mills, and temperatures measured downstream at Blossom Road were 5 to $7^{\circ} \mathrm{F}$ warmer than at Railroad Mills. The relatively high temperatures at the downstream sites likely reflect urbanization effects, including heated runoff from roofs and asphalt roads and the urban heat island effect (Somerfield, 2010).

The New York State Department of Environmental Conservation (NYSDEC; 1991) restricts high temperatures in water discharged to trout streams. The regulations stipulate that no discharge will exceed $70^{\circ} \mathrm{F}$, and no discharge from June through September will increase a stream's temperature by more than $2^{\circ} \mathrm{F}$. Although no direct discharges were monitored as part of this study, the maximum recorded daily water temperatures during $2003-08$ exceeded $72^{\circ} \mathrm{F}$ on many consecutive days during the summer and early autumn months at all monitoring sites except Railroad Mills. Infrequently, the water temperature at some of these sites exceeded $72^{\circ} \mathrm{F}$ for an entire day. Cold-water fish are stressed by these high temperatures (Elliott, 1981), but no fish die offs have been reported. 


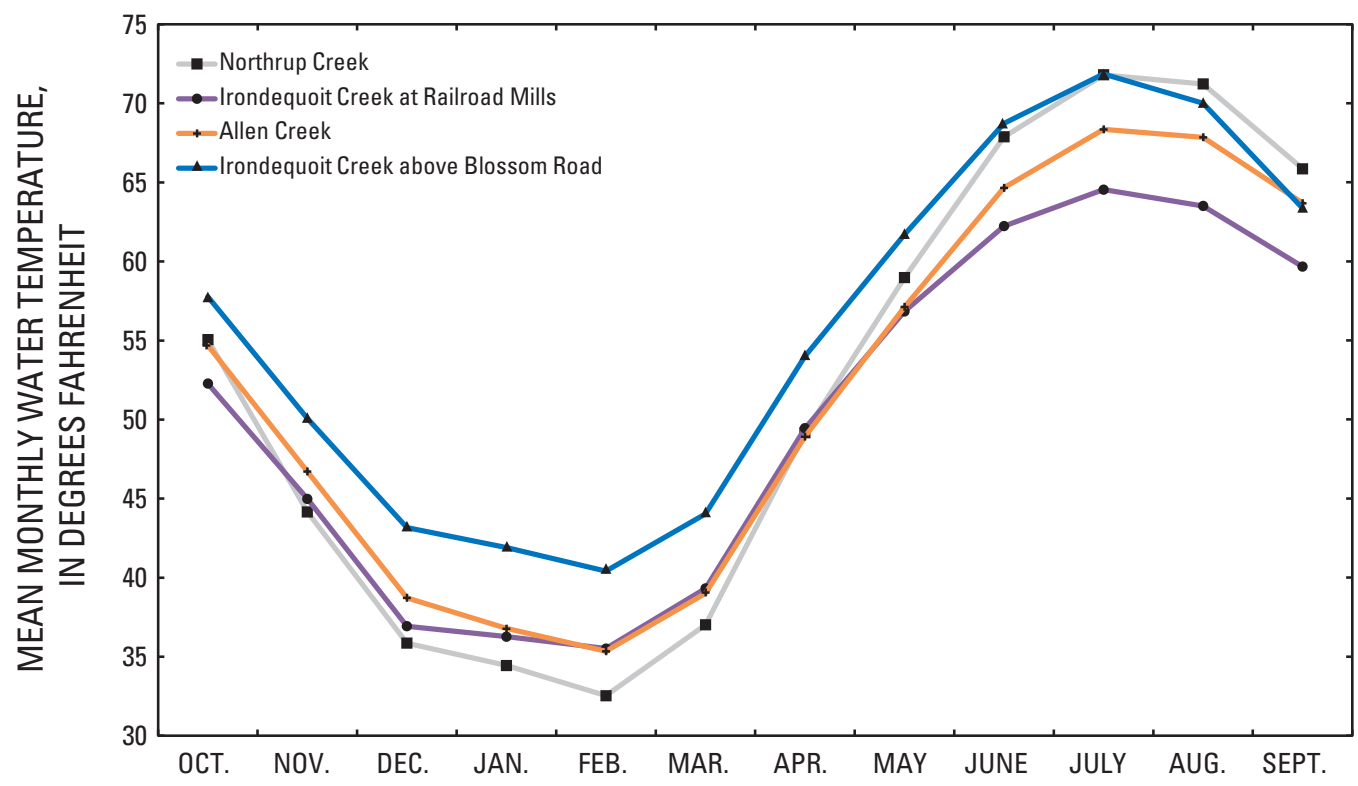

Figure 6. Mean monthly water temperatures at four monitoring sites in Monroe County, N.Y., water years 2003-08.

\section{Chemical Constituents}

A summary of all constituent concentrations at the nine monitoring sites for water years 2003-08 is shown in table 3 . Median values were presented in the table as a measure of central tendency rather than the mean because the median is insensitive to extreme values in the data.

\section{Nutrients and Total Suspended Solids}

Northrup Creek had the highest median annual concentrations of phosphorus, orthophosphate, and ammonia plus organic nitrogen of the nine monitored streams (table 3). The 2003-08 median concentrations of phosphorus and orthophosphate, $0.162 \mathrm{mg} / \mathrm{L}$ and $0.050 \mathrm{mg} / \mathrm{L}$, respectively, were almost twice as great as those at most of the other monitoring sites. The 2003-08 median concentration of ammonia plus organic nitrogen was $0.97 \mathrm{mg} / \mathrm{L}$. These results were primarily attributed to the village of Spencerport wastewater-treatment plant; discharges from the plant increased the concentrations of all measured constituents in Northrup Creek, except sulfate (based on a comparison of data concurrently collected from Northrup Creek and the outflows from the wastewater-treatment plant and the canal during 2001-03; U.S. Geological Survey, 2009a). Diversions from the NYS Erie (Barge) Canal actually had a diluting effect on ambient concentrations for all constituents, except sulfate. Other possible contributors to the high nutrient concentrations in Northrup Creek include manure and fertilizers applied to agricultural fields.
In the Genesee River, median annual concentrations of phosphorus $(0.122 \mathrm{mg} / \mathrm{L})$ and orthophosphate $(0.018 \mathrm{mg} / \mathrm{L})$ were also high, and the maximum sample concentrations of the study were $0.977 \mathrm{mg} / \mathrm{L}$ for phosphorus and $0.401 \mathrm{mg} / \mathrm{L}$ for orthophosphate. The high phosphorus concentrations in the Genesee River presumably reflect solid-phase transport associated with the large suspended-sediment loads that are derived from agricultural areas in the basin and from streambank erosion (New York State Department of Environmental Conservation, 2003). Although not always correlated with suspended-sediment concentrations (Gray and others, 2000), total suspended solids concentrations are often used as a substitute for suspended-sediment concentrations. Compared to the other study sites, the Genesee River had a relatively high median annual concentration $(44 \mathrm{mg} / \mathrm{L})$ and the highest measured concentration of total suspended solids $(1,890 \mathrm{mg} / \mathrm{L})$.

Median annual concentrations of nitrate plus nitrite nitrogen were highest in Oatka Creek, Northrup Creek, and Black Creek, basins with substantial agricultural areas. The maximum sample concentrations of nitrate plus nitrite nitrogen, which occurred during winter periods, were $4.53 \mathrm{mg} / \mathrm{L}$ for Black Creek and $3.70 \mathrm{mg} / \mathrm{L}$ for Oatka Creek. In the Black Creek Basin, two factors could have had an effect on nutrient concentrations. The Byron-Bergen Swamp (Genesee County, 2009), which extends from 3 to 8 mi west of Churchville, and a dam in Churchville about $1,700 \mathrm{ft}$ upstream from the monitoring site, which creates an impoundment that extends over $2.5 \mathrm{mi}$ upstream, presumably would have mitigative effects on particulate and sediment loads, but these effects have not been assessed. 

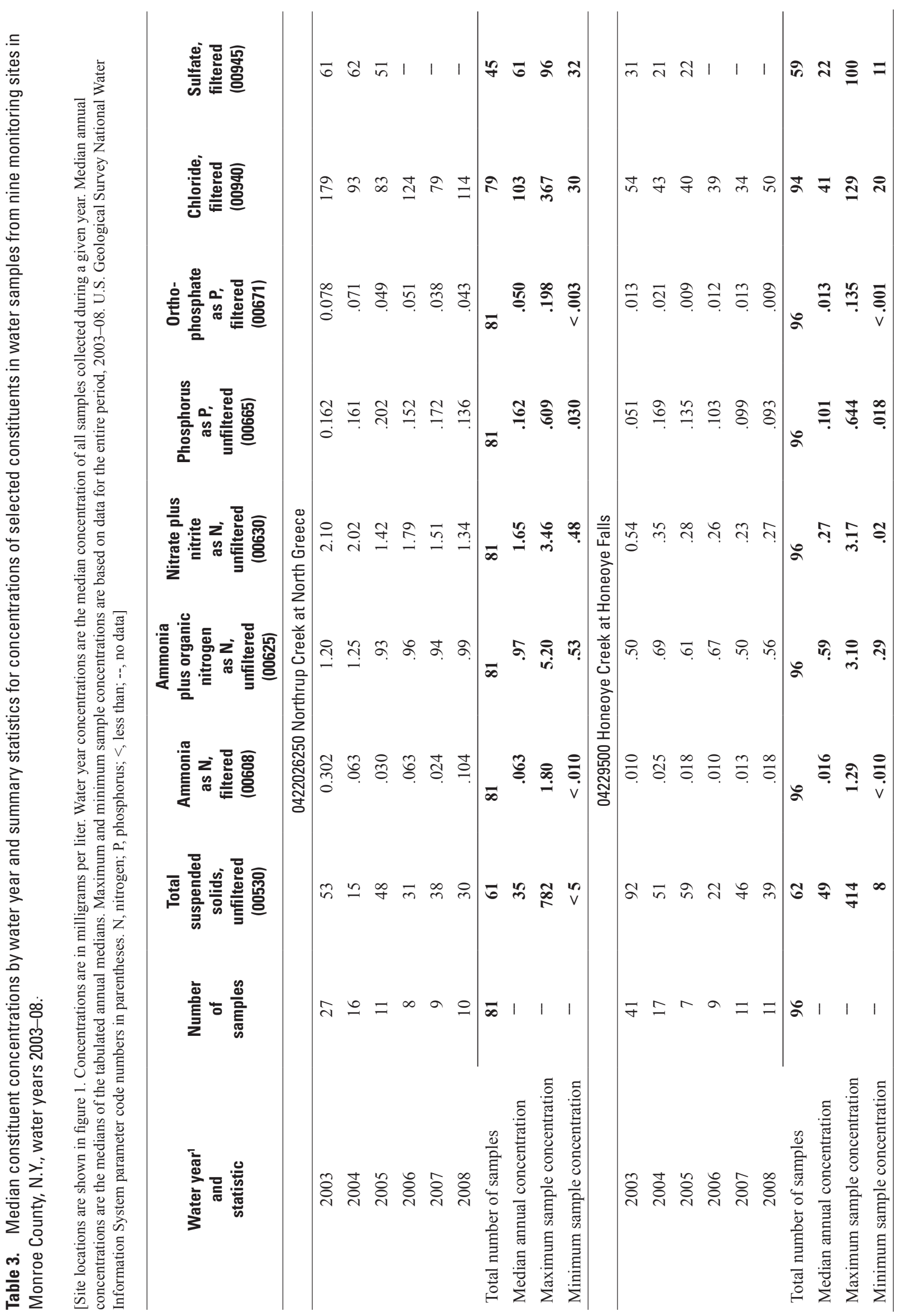


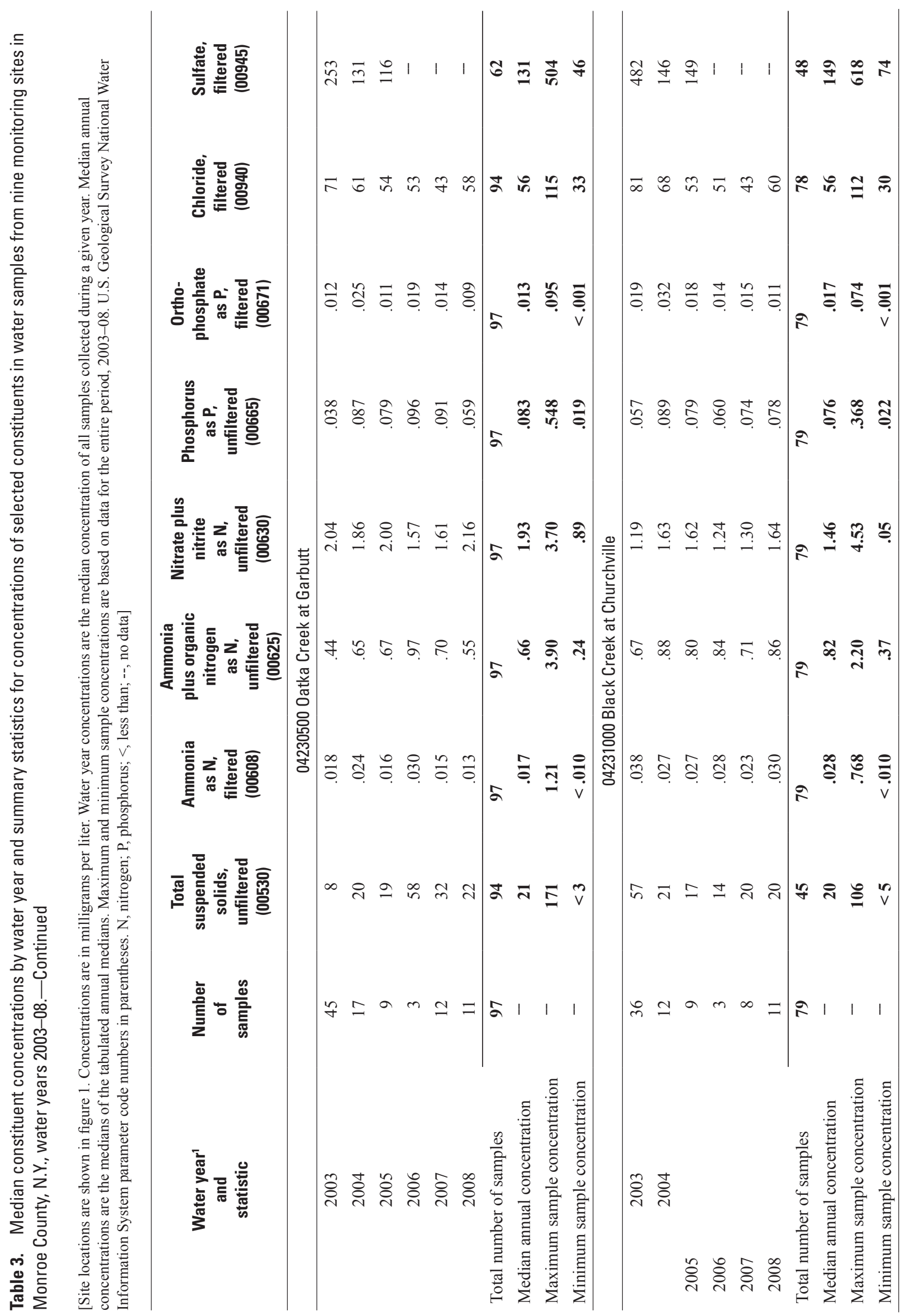




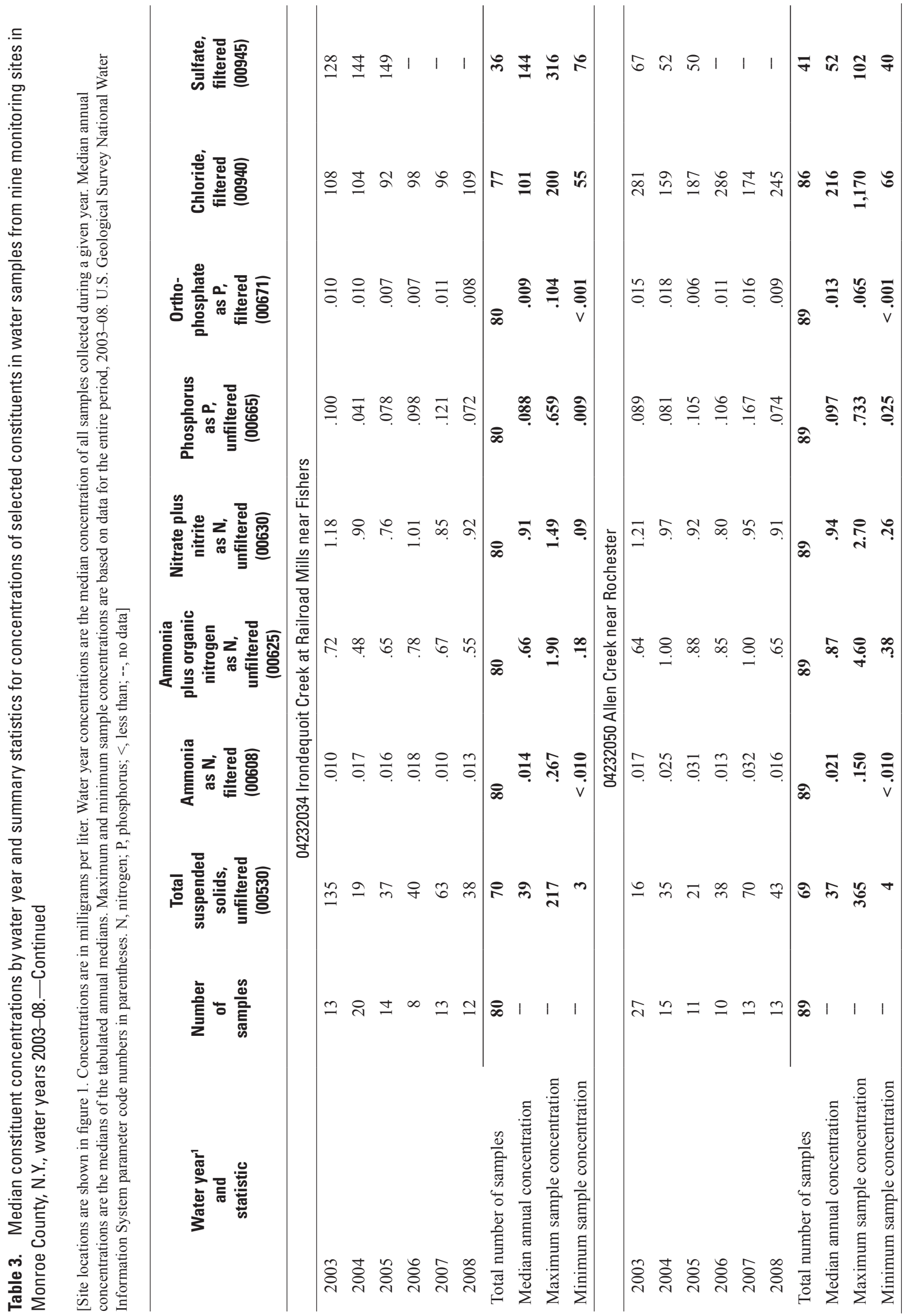




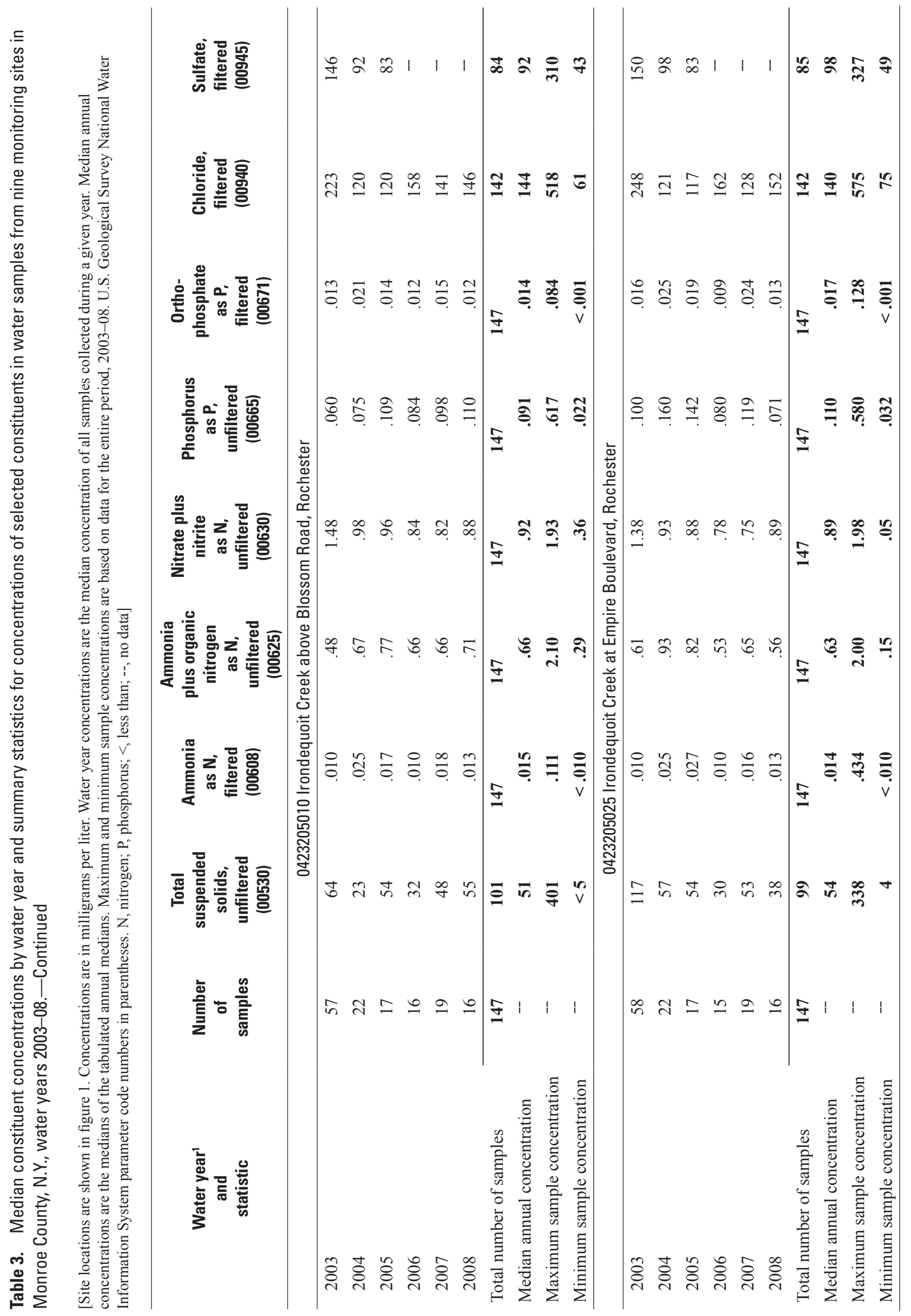




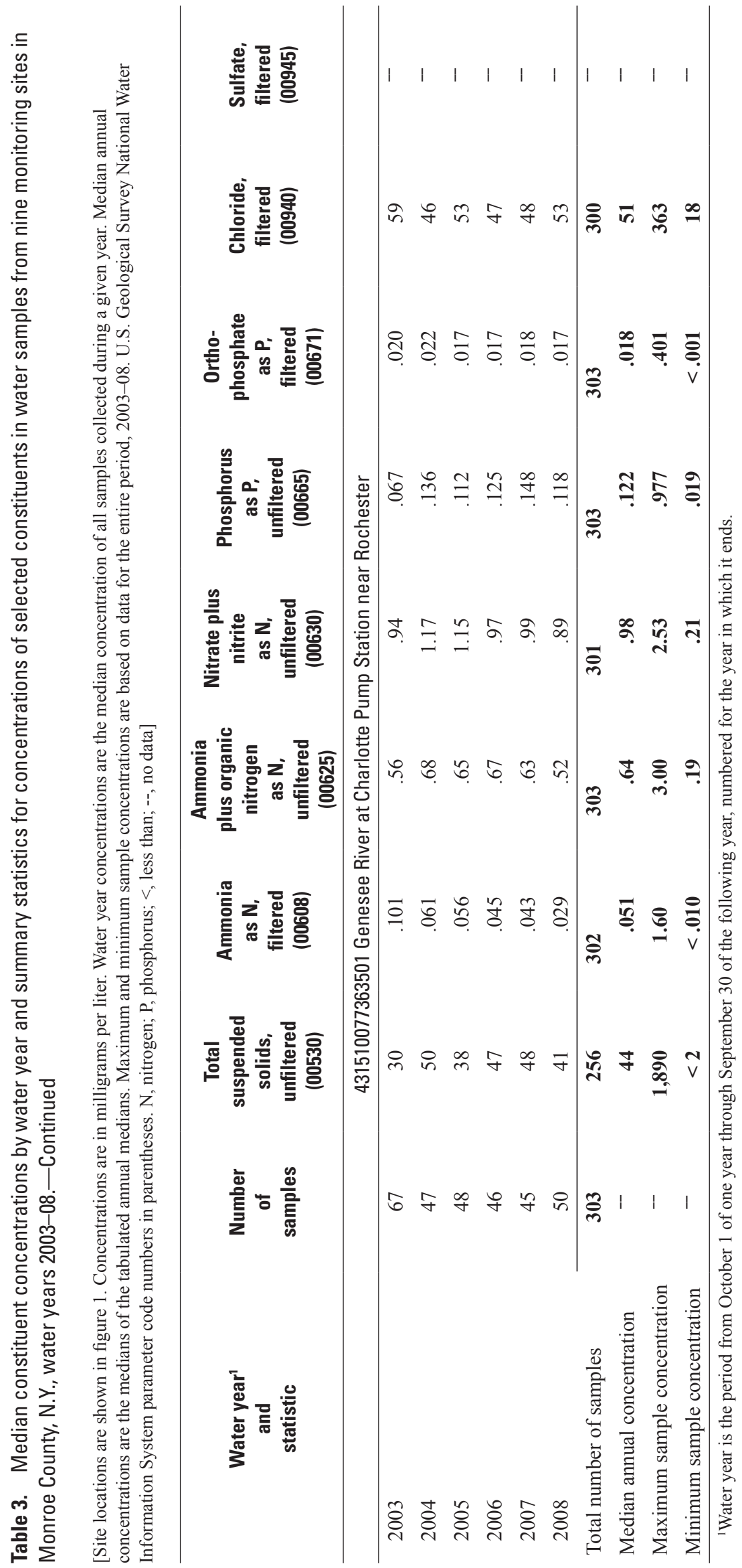




\section{Chloride and Sulfate}

The primary source of chloride in Monroe County is road-deicing salt (sodium chloride) used during the winter; over 120,000 tons of salt were applied to Monroe County roads during the winters of 2000-02 (Sherwood, 2005; table 16). The deleterious effects of road salt on the water quality of Monroe County streams (Monroe County Water Quality Planning Bureau, 2001) and Irondequoit Bay (Bubeck and Burton, 1989) are well documented. Chloride concentrations were highest in the urban basins where population, road densities, and salt-application rates (Sherwood, 2005) were greater than those in rural basins. Of all the monitoring sites, Allen Creek had the highest median annual concentration of chloride $(216 \mathrm{mg} / \mathrm{L})$ and the highest measured concentration $(1,170 \mathrm{mg} / \mathrm{L})$. The lowest concentrations of chloride were found in Honeoye Creek and the Genesee River, which had median annual chloride concentrations of 41 and $51 \mathrm{mg} / \mathrm{L}$, respectively (table 3 ). Both Oatka Creek and Black Creek had median annual chloride concentrations of $56 \mathrm{mg} / \mathrm{L}$.

Concentrations of sulfate were measured in samples collected only during 2003-05 for all sites, except Genesee River at Charlotte Pump Station, for which sulfate concentrations were not analyzed. Median annual concentrations of sulfate ranged from $22 \mathrm{mg} / \mathrm{L}$ in Honeoye Creek to $149 \mathrm{mg} / \mathrm{L}$ in Black Creek. The highest concentrations of sulfate, 618 and $504 \mathrm{mg} / \mathrm{L}$, were measured in Black Creek and Oatka Creek, respectively. Relatively high sulfate concentrations also were measured in Irondequoit Creek at Railroad Mills. These high concentrations are attributed to dissolution of sulfate from thick gypsum (calcium sulfate) layers in Silurian shale bedrock (Broughton and others, 1962) that crops out upstream from these monitoring sites (Young, 1993). The Honeoye Creek monitoring site lies south (upstream) of the gypsum-bearing outcrops and springs; hence, sulfate concentrations at this site did not reflect this source. Sulfate in the urbanized lower parts of the Irondequoit Creek Basin, which generally lie north of the gypsum-bearing outcrops, was attributed to the Silurian shale outcrops but also to atmospheric deposition from industrial and transportation sources. The median annual concentrations of sulfate in Irondequoit Creek decreased from $144 \mathrm{mg} / \mathrm{L}$ at Railroad Mills to $92 \mathrm{mg} / \mathrm{L}$ downstream at Blossom Road.

\section{Constituent Loads}

Load calculations provide an estimate of the amount (mass per unit of time) of a given constituent that moves in streamflow past a given point (water-quality monitoring site) or into a receiving body of water. Knowledge of the magnitude and trends in loads of chemical constituents is important in evaluating transport processes and assessing the effectiveness of management practices that may control constituent sources within the basin.
In this study, the USGS LOADEST program (Runkel and others, 2004; Cohn and others, 1992) was used to estimate daily mean constituent concentrations and loads through a log-linear regression model that uses streamflow, time, and seasonal indicators (cyclic sine and cosine functions of time) as explanatory variables. The program handles censored concentrations (those values found to be below an analytical detection limit) through an adjusted maximum likelihood estimation routine. Regression coefficients and associated $t$-statistics for each explanatory variable are calculated, and daily loads are computed from the estimated daily mean constituent concentrations and measured daily mean flows. The daily load estimates are summed to derive monthly and annual totals. In this report, the model variables were retained only when $t$ values for the estimated regression coefficients exceeded 95-percent confidence levels (a probability $[p]$ less than 0.05 indicates that the coefficient was not statistically different from zero).

The LOADEST regression coefficients can be directly related to basin characteristics or to physical and biological processes. For example, the linear dependence of logtransformed concentration on log-transformed streamflow may be indicative of the source of the constituent; negative coefficient values indicate a dilution effect on point sources, and positive values generally indicate nonpoint (spatially diffuse) sources and reflect increased transport during periods of storm runoff and high streamflow. The magnitude and the positive (increasing) or negative (decreasing) component of the linear time variable indicates the presence and direction of a monotonic trend in constituent load for the 6-year study period. The presence of a seasonal (annually cyclic) trend is determined through the regression coefficients for a combined sine-plus-cosine Fourier function. The overall dependence of concentration and load on the variables-flow $\left(\mathrm{Q}\right.$ and $\left.\mathrm{Q}^{2}\right)$, monotonic time trend $(\mathrm{T})$, and seasonal trend (based on a sinusoidal function, $\mathrm{SS}$ ) - is measured by the coefficient of determination $\left(\mathrm{R}^{2}\right)$, which describes the amount of variance in constituent loads explained by the model. The statistically significant model variables, the $\mathrm{R}^{2}$ coefficients, and the estimated annual loads are summarized in table 4 for five constituents at the nine sites. Insufficient data precluded load and trend analyses for ammonia, total suspended solids, and orthophosphate.

Loads of chloride, sulfate, ammonia plus organic nitrogen, nitrate plus nitrite nitrogen, and phosphorus at most study sites were estimated using a regression model. Statistically significant positive flow-related coefficients were determined for all constituents at five study sites. For three sites, insufficient data precluded estimation of loads using the regression model. Loads were estimated as the product of the median constituent concentrations (2003-08) and annual mean flow for phosphorus at Northrup Creek and Oatka Creek, and for nitrate plus nitrite nitrogen at Honeoye Creek. For one site, Genesee River near Rochester, sulfate concentrations were not measured; therefore, sulfate loads were not estimated. All other constituent loads at the nine sites were positively 


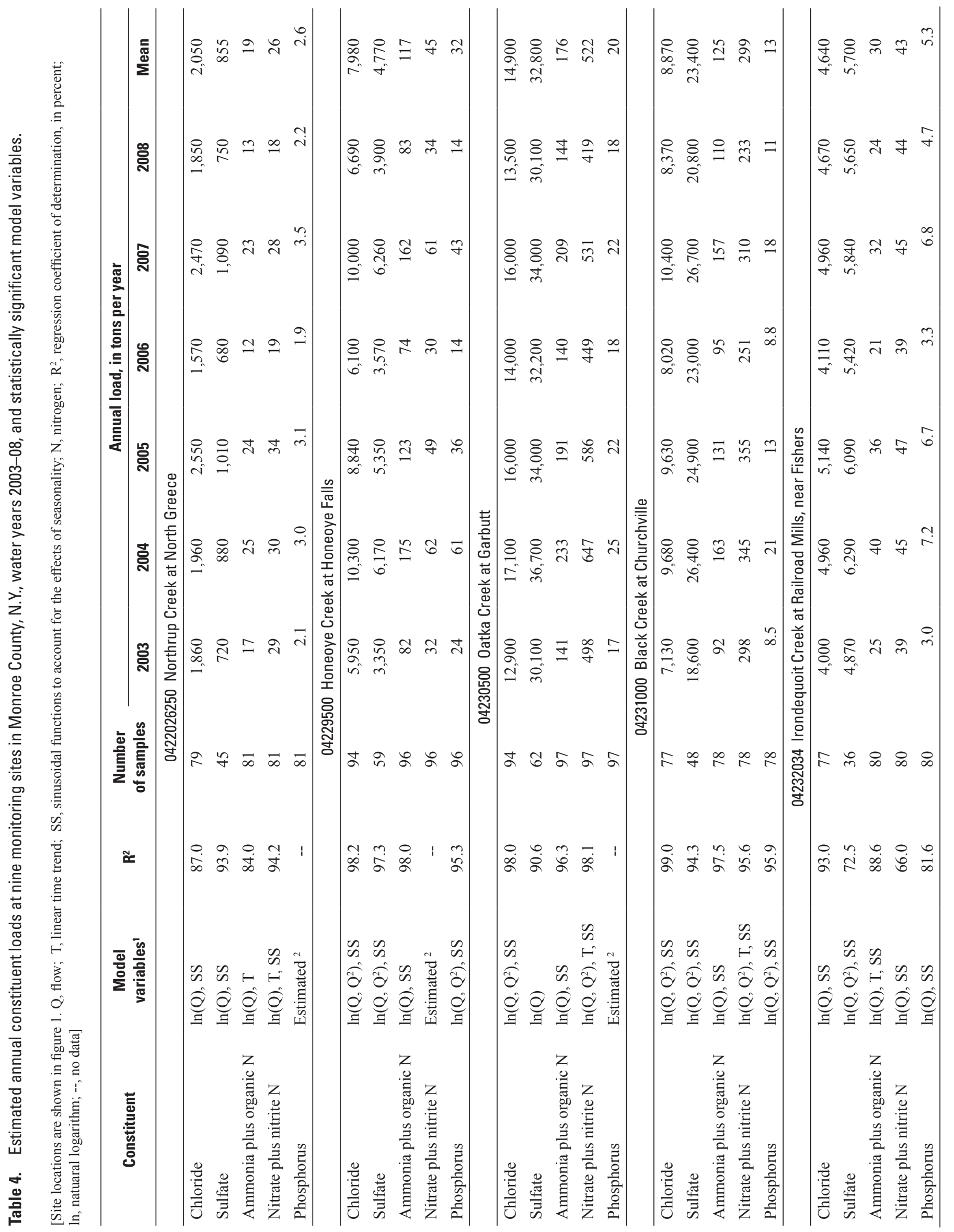




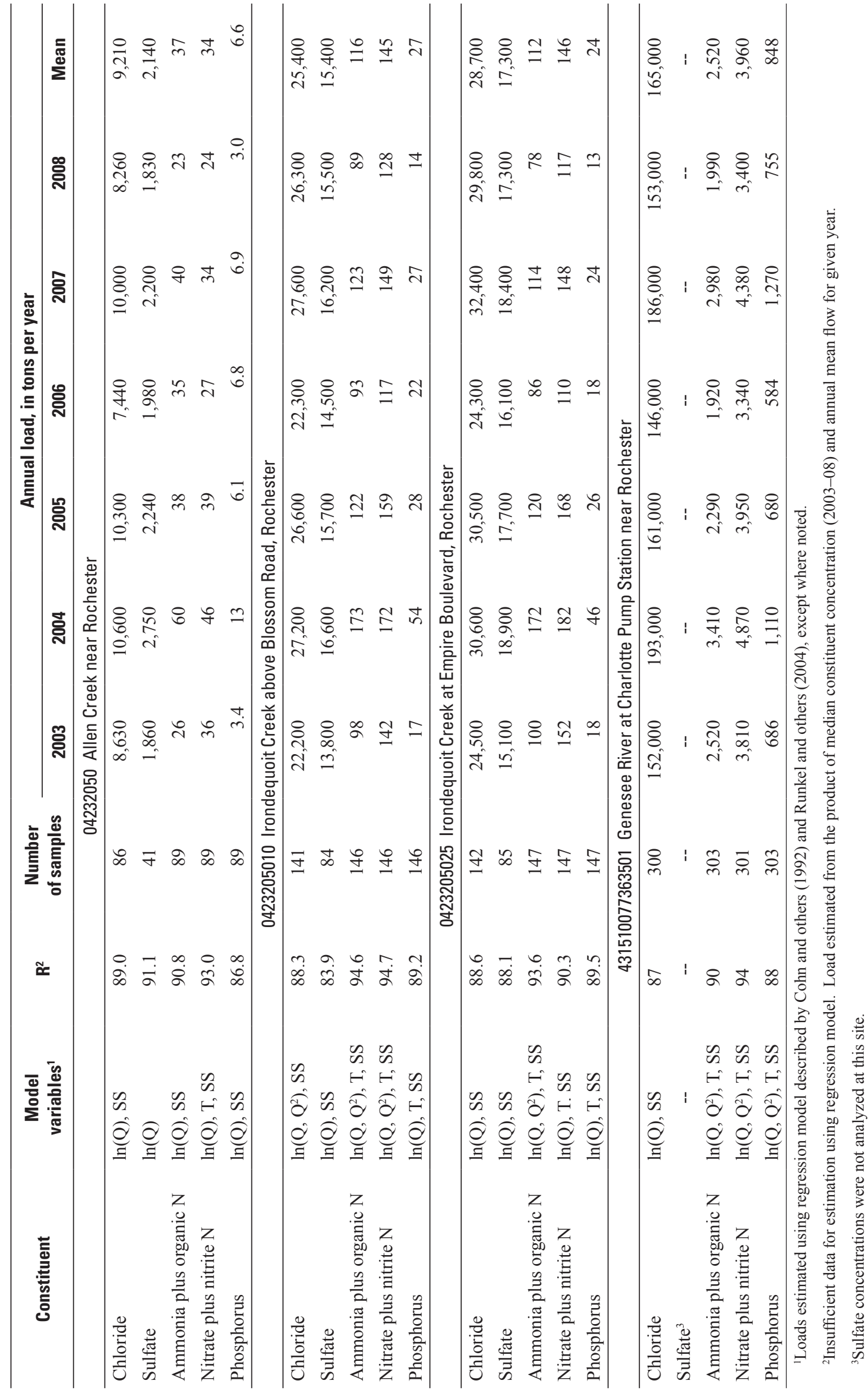


correlated with streamflow, indicating that loads in these streams were dominated by runoff and nonpoint sources. For example, the loads of chloride were derived from the application of road salt to paved areas throughout the study area during winter months and were transported to streams in runoff during rainfall and snowmelt. A discussion of the seasonal and monotonic time trends is presented in the next section of the report.

Because constituent loads were directly related to streamflow, the large basins generated large constituent loads simply by virtue of their size (table 4). Basin-tobasin comparisons of constituent transport were enabled by normalizing the load data by basin area to derive constituent yield (load per unit area). Annual yields of the five constituents are summarized for the nine study sites in table 5 and figure 7.

Annual yields of chloride (fig. 7A) were greatest in the urbanized basin of Allen Creek (250 to 350 ton $/ \mathrm{mi}^{2}$ ), where roads received large applications of road-deicing salt in winter months. The lower Irondequoit Creek Basin also had relatively large yields of chloride (160 to $220 \mathrm{ton} / \mathrm{mi}^{2}$ ) due to road-salt applications. The basins with low population and road densities-Honeoye Creek, Black Creek, Oatka Creek, and Genesee River-had relatively low yields of chloride (30 to 86 ton $/ \mathrm{mi}^{2}$ ). An apparent anomaly among the results was the chloride data from Northrup Creek. Compared to loads at the other monitoring sites, the total loads of chloride in Northrup Creek were small; however, the yields of chloride ranked second (160 to 250 ton $/ \mathrm{mi}^{2}$ ) after those computed for Allen Creek. The results indicated that road-salt application in Spencerport and chloride in discharges from the Spencerport wastewater-treatment plant probably contributed to the high chloride yields in this stream; however, an as-yet-unidentified natural source could have been a contributing factor.

Although sulfate concentrations were not measured in water samples collected during the 2006-08 water years, loads and yields were computed for these years from the regression equations developed with the 2003-05 data. No sulfate loads or yields were computed for the Genesee River because sulfate-concentration data were not available. Sulfate yields (fig. 7B) were greatest in Black Creek, Oatka Creek, and Irondequoit Creek in the upper basin (120 to 210 ton/ $\mathrm{mi}^{2}$ ), which drain areas where Silurian bedrock contains thick beds of gypsum (Broughton and others, 1962). The gypsum beds crop out downstream from the Honeoye Creek monitoring site and likely contributed to the lowest measured sulfate yields (17 to 32 ton $/ \mathrm{mi}^{2}$ ).

Nitrogen yields in Northrup Creek were generally greater than at other sites, presumably as a result of the discharge of water (fig. 5) and nutrients to the creek from the Spencerport wastewater-treatment plant. The Erie (Barge) Canal was a second source of nutrients to the creek. On the basis of limited data that were collected during 2001-03 (U.S. Geological Survey, 2009a), constituent concentrations in canal water generally were lower than concentrations in concurrently collected creek water; however, the constituent loads from the canal were large owing to the near-constant flow from this source. The combined contributions from the wastewatertreatment plant and the canal were estimated from the 2001-03 data (U.S. Geological Survey, 2009a); these estimates indicate that 30 to 40 percent of the computed loads of ammonia plus organic nitrogen, nitrate plus nitrite nitrogen, and phosphorus in Northrup Creek at Greece could be attributed to the loads input from these two sources.

The high yields of nitrate plus nitrite nitrogen (1.8 to 3.4 ton $/ \mathrm{mi}^{2}$; fig. $7 \mathrm{C}$ ) and ammonia plus organic nitrogen (1.2 to 2.5 ton/ $\mathrm{mi}^{2}$; fig. 7D) in Northrup Creek also could have been derived from fertilizers and manure that were applied to agricultural land within the Northrup Creek Basin. The basins of Oatka Creek and Black Creek also had substantial agricultural sources of nitrogen that are reflected in relatively high yields of nitrate plus nitrite nitrogen (1.8 to 3.2 ton $/ \mathrm{mi}^{2}$; fig. 7C) for these streams. In contrast, Honeoye Creek Basin is relatively undeveloped, has less intensive agricultural use than the Oatka Creek and Black Creek Basins, and has low streamflow yield (fig. 5); all factors that contribute to relatively low nitrogen yields. Allen Creek had the second highest yields of ammonia plus organic nitrogen (0.76 to 2.0 ton $/ \mathrm{mi}^{2}$; fig. $\left.7 \mathrm{D}\right)$.

The Ellison Park wetland, a 423-acre predominantly cattail marsh, covers the Irondequoit Creek valley bottom between the Blossom Road and Empire Boulevard monitoring sites. The natural mitigative effects of the wetland on constituent loads, especially those of particulate constituents, which would otherwise be transported to Irondequoit Bay, have been documented by Coon (2000). During February 1997, a flow-control structure designed to increase the dispersal and short-term detention of storm runoff in the wetland was installed mid-way through the wetland at a point locally referred to as the Narrows. This structure increased the wetland's removal efficiency for phosphorus from 28 to 45 percent and that of total suspended solids from 47 to 52 percent (Coon, 2004). The continued mitigative effects of the wetland and the flow-control structure on phosphorus and ammonia plus organic nitrogen loads were evident in this study (2003-08 water years). Yields of phosphorus were 16 percent lower, and yields of ammonia plus organic nitrogen were 9 percent lower, at Empire Boulevard than at Blossom Road (fig. 7D and 7E; table 5). Yields of dissolved constituents (chloride, sulfate, and nitrate plus nitrite nitrogen) were similar at both sites, a result that Coon (2004) found for these constituents from data collected during 1990-2001. The flow-control structure was removed during March and July 2009 by order of the Regulatory Branch of the U.S. Army Corps of Engineers after evaluation of the potential future benefits to Irondequoit Bay and the expected adverse effects of the control structure on the wetland ecology (P.D. Frapwell, U.S. Army Corps of Engineers, written commun., 2007).

Estimated yields for the Genesee River (table 5) reflect constituent loads (table 4) that were delivered to Lake Ontario $0.5 \mathrm{mi}$ downstream from the monitoring site. The relatively high yields of phosphorus for the Genesee River 


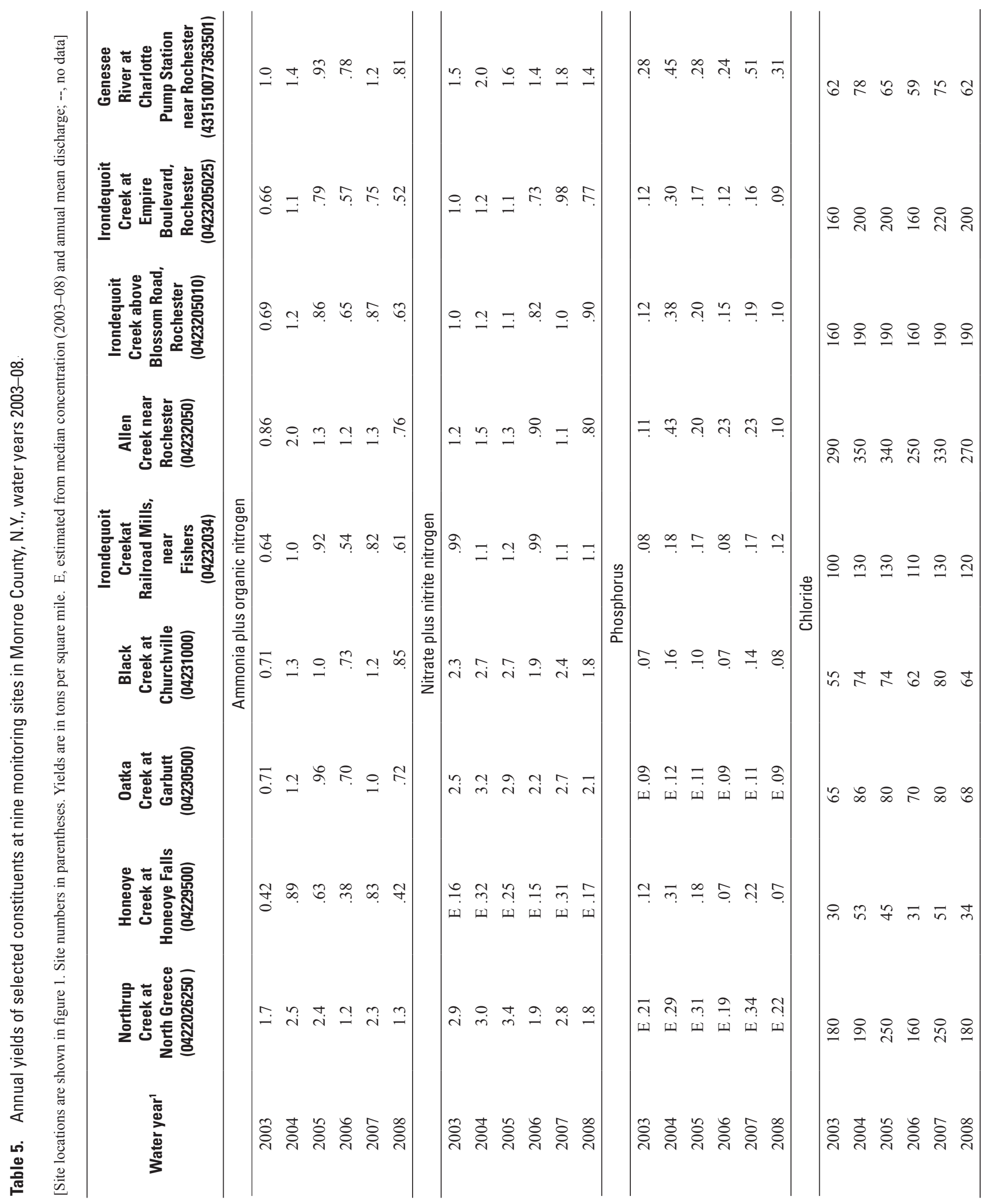




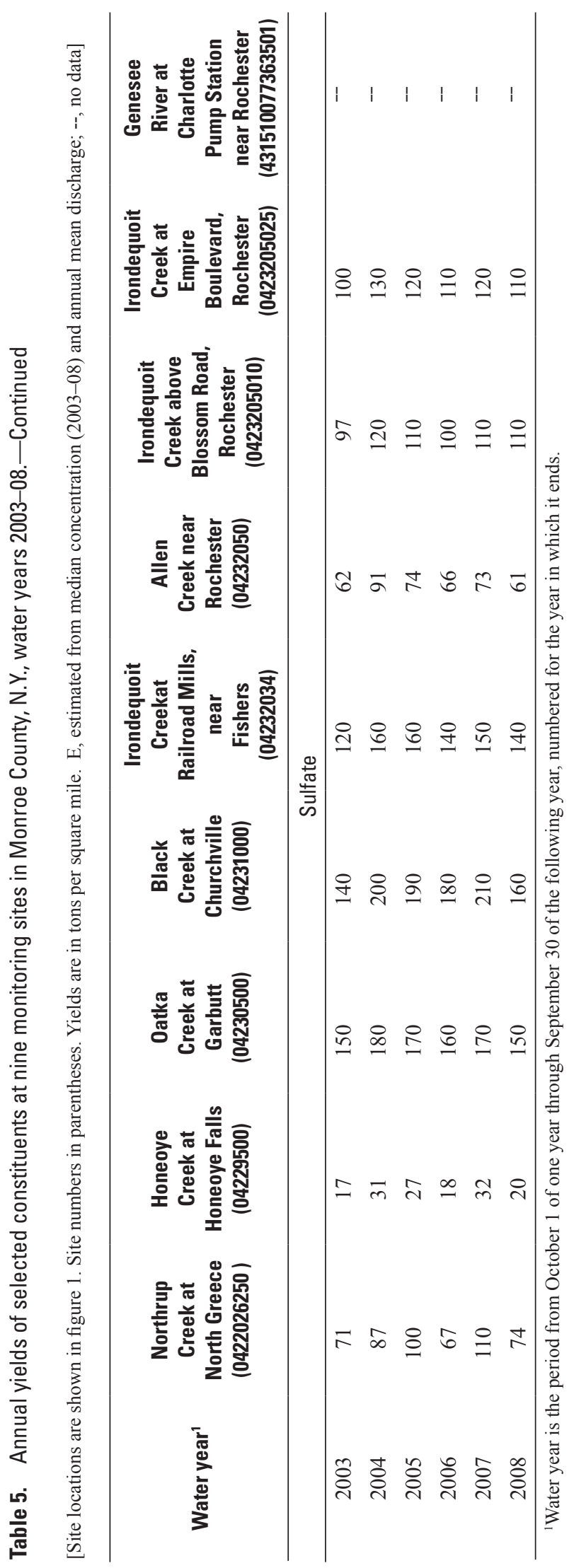



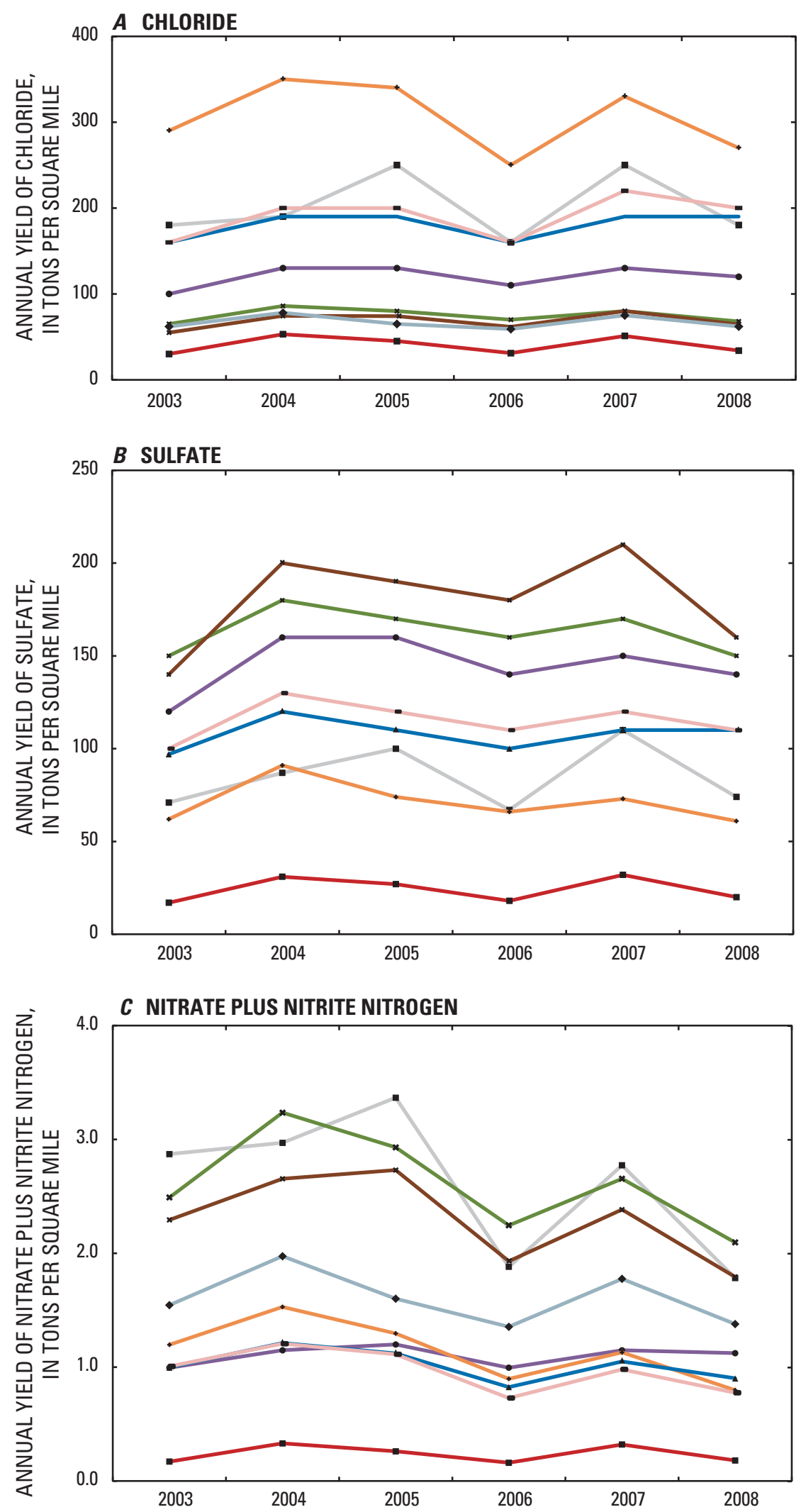

Figure 7. Annual yields of selected constituents at nine monitoring sites in Monroe County, N.Y., water years 2003-08: $A$, chloride; $B$, sulfate; $C$, nitrate plus nitrite nitrogen; $D$, ammonia plus organic nitrogen; and $E$, phosphorus. 
D AMMONIA PLUS ORGANIC NITROGEN

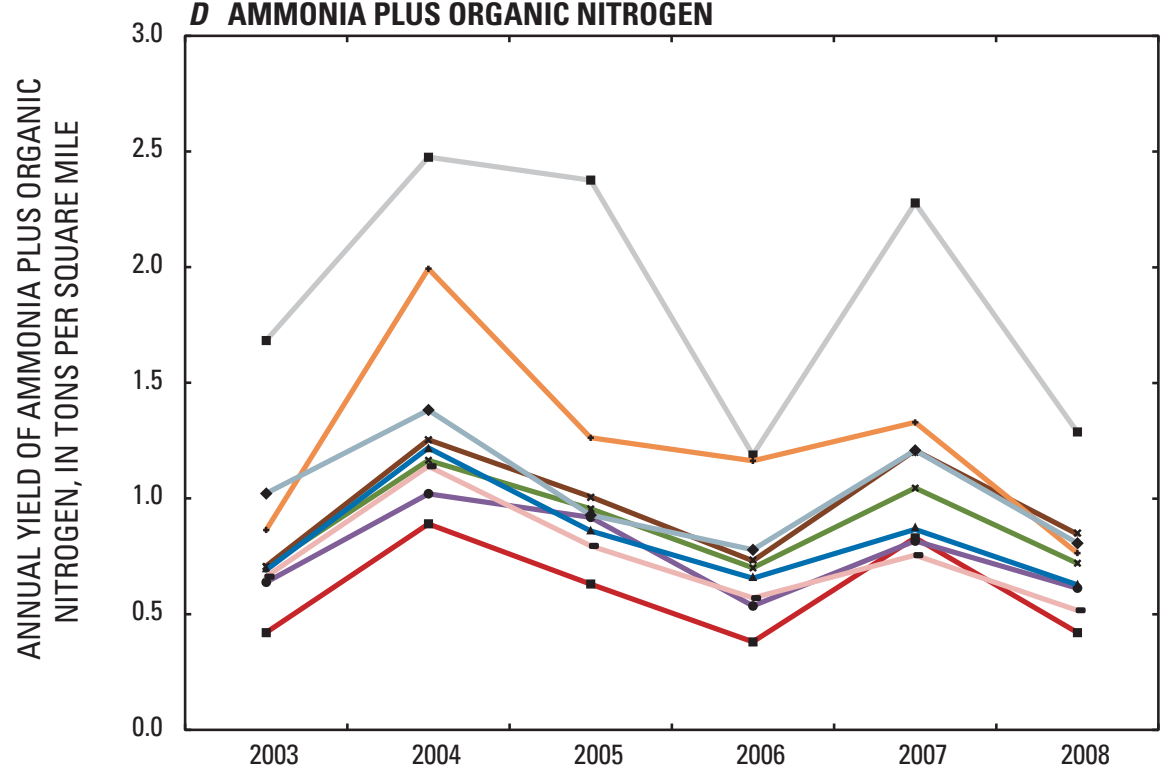

E PHOSPHORUS

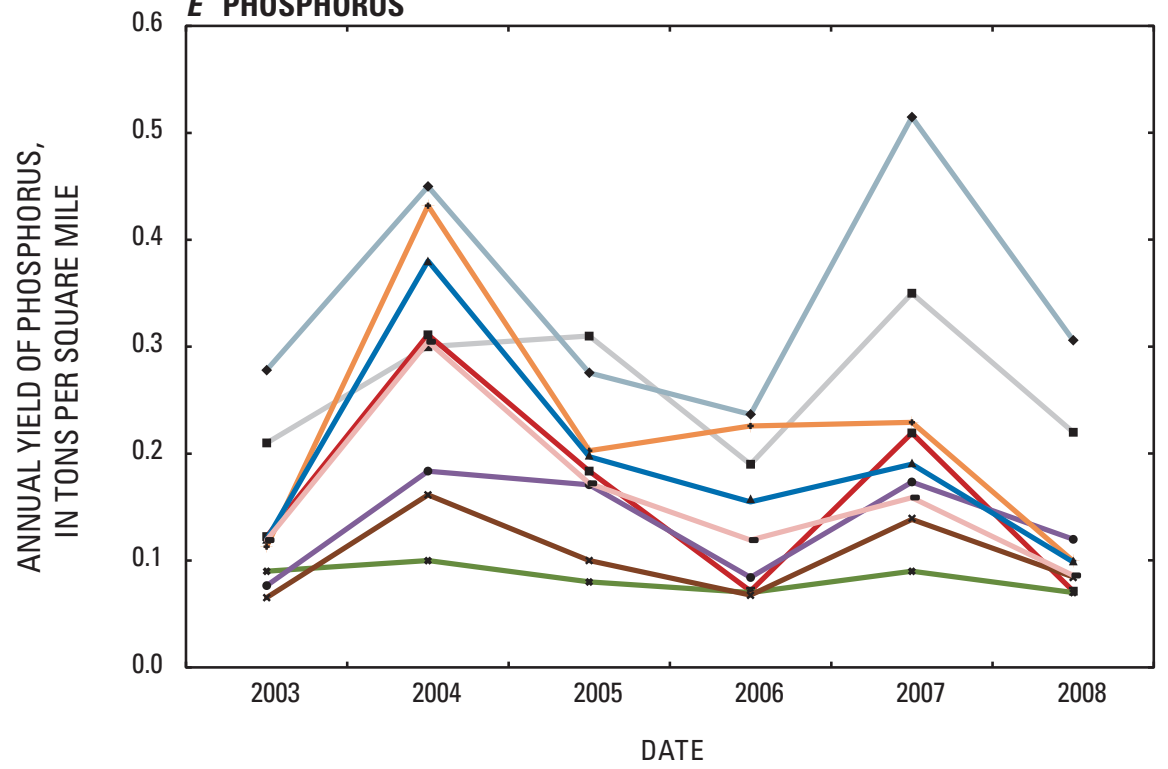

\section{EXPLANATION}

- Northrup Creek

$\rightarrow$ Honeoye Creek

*-Oatka Creek

* Black Creek

$\because$ Irondequoit Creek at Railroad Mills

- Allen Creek

- Irondequoit Creek above Blossom Road

- Irondequoit Creek at Empire Boulevard

- Genesee River at Charlotte pump station

Figure 7. Annual yields of selected constituents at nine monitoring sites in Monroe County, N.Y., water years 2003-08: $A$, chloride; $B$, sulfate; $C$, nitrate plus nitrite nitrogen; $D$, ammonia plus organic nitrogen; and $E$, phosphorus.-Continued 
( 0.24 to $0.51 \mathrm{ton} / \mathrm{mi}^{2}$; fig. 7E) were associated with suspendedsediment generated from agricultural areas and streambank erosion (New York State Department of Environmental Conservation, 2003).

\section{Temporal Trends}

A shift in population from Rochester to the surrounding townships over the past few decades has resulted in the conversion of agricultural and forested land to residential and commercial uses; this process has slowed in some towns in recent years, however. Monotonic time-trend and seasonaltrend analyses can be used to assess the effect of development on surface-water quality within the study basins.

A monotonic time trend, as used in this report, is a linear change (increase or decrease) in the concentration of a given constituent at a specific sampling site over the 6-year study period. Seasonal trends are annually cyclic patterns that are seen each year. The USGS software program ESTREND (EStimate TREND; Shertz and others, 1991) was used to discern both types of trend through a linear model that uses an adjusted maximum-likelihood estimation approach. The trends are considered to be statistically significant when the $t$-statistic for each trend coefficient has a $p$ value less than 0.05 , which indicates a 95-percent confidence level that the estimated trend in concentration is valid. Generally, the monotonic trend tests require at least 5 years of data for reliable results (Hirsch and others, 1982). In the analysis, variability in constituent concentrations resulting from variations in streamflow was minimized through regression of log-transformed concentrations as a function of log-transformed flows. This regression produced a residual (flow-adjusted) concentration that was then used in the trend tests. The effects of seasonal (annually cyclic) trends, if present, were removed through a set of sine-plus-cosine Fourier functions. The flow and seasonally adjusted concentrations were then used to evaluate the slope of the monotonic trend rate (Sen, 1968), its positive or negative sign (increasing or decreasing concentration over time), and significance ( $p$ value less than 0.05).

Monotonic time trends were identified at all sites for most of the nutrient constituents that were evaluated (table 6). All of the monotonic time trends detected in the nutrient data indicate that concentrations decreased (negative rates in table 6) during the 6-year study period, with one exception-phosphorus. Phosphorus concentrations increased by 5.7 percent at the Genesee River monitoring site. At four other sites (table 6), phosphorus concentrations decreased during the study period. Nitrate plus nitrite nitrogen concentrations decreased at all sites except Irondequoit Creek at Railroad Mills where a trend was not detected. The general decrease in nutrient concentrations was most notable for Irondequoit Creek at
Empire Boulevard, where the mitigative effects of the Ellison Park wetland and the flow-control structure at the Narrows were evident. Monotonic trends in chloride concentrations were not detected at any site.

Constituent concentrations typically reflect seasonal variations in biochemical or hydrologic processes or human activities (fig. 8). In this study, seasonal trends in concentration were identified at all sites for nearly every constituent that was evaluated (table 6). The seasonal variability in constituent concentrations and flow is reflected in the transport of constituent loads (fig. 9). For example, the seasonal nature of the chloride concentrations and loads for the suburban, developed basin of Allen Creek are shown in figure $8 \mathrm{~A}$ and figure $9 \mathrm{~A}$. The effect of road-salt applications to paved areas throughout the basin during winter months is shown by chloride loads that were four to eight times higher in runoff during winter and early spring than during summer months. Chloride concentrations in streams are typically highest in January and February, whereas high loads of chloride persist from January through April as runoff is augmented by snowmelt in early spring. The same general pattern of seasonal chloride transport is seen in the other study basins.

The concentrations and loads of the nitrogen constituents were generally highest during late fall through spring, when fertilizers and manure applied to residential lawns or fallow farm fields are transported to streams by snowmelt and spring rains and when denitrification (bacterial transformation of nitrate) is minimal. During summer months, nitrate transport is minimal because of low flows, limited nitrogen applications on growing crops, and biologically active denitrification processes. As an example, the seasonal nature of the nitrate plus nitrite nitrogen concentrations and loads for the largely agricultural basin of Oatka Creek are shown in figure $8 \mathrm{~B}$ and figure 9B. The same general pattern was seen in the other study basins, including the suburban developed basin of Allen Creek.

The loads of phosphorus and other constituents (table 4; fig. 7) at the Genesee River site, for the most part, are delivered directly to Lake Ontario. The seasonal nature of the phosphorus concentrations and loads for the largely agricultural basin of the Genesee River are shown in figure 8C and figure 9C. As with the nitrogen species, phosphorus in soils, fertilizers, and manure is eroded and transported during storm runoff, and the transport process is most significant during late fall, winter, and early spring months when fields are fallow and runoff is often high. The monthly pattern of concentrations and loads of phosphorus differs slightly from that of nitrate plus nitrite nitrogen, in part, because phosphorus is affected more by runoff processes that control solid-phase particulate transport, whereas nitrate is transported largely in a dissolved phase. 
Table 6. Trends in concentrations of selected constituents at nine monitoring sites in Monroe County, N.Y., water years 2003-08.

[Site locations are shown in figure 1. $\mathrm{mg} / \mathrm{L}$, milligrams per liter; $\mathrm{nd}$, trend not detected; --, insufficient data for trend analysis; $\mathrm{p}$, probability that trend is not statistically significant]

\begin{tabular}{|c|c|c|c|c|}
\hline \multirow{2}{*}{ Constituent } & \multirow{2}{*}{$\begin{array}{c}\text { Number of } \\
\text { samples }\end{array}$} & \multirow{2}{*}{ Seasonal trend ${ }^{1}$} & \multicolumn{2}{|c|}{ Monotonic trend in concentration ${ }^{2}$} \\
\hline & & & (mg/L per year) & (percent per year \\
\hline \multicolumn{5}{|c|}{0422026250 Northrup Creek at North Greece } \\
\hline Chloride & 79 & Yes & nd & nd \\
\hline Sulfate & 45 & Yes & -- & -- \\
\hline Ammonia plus organic nitrogen & 81 & nd & -0.05 & -5.0 \\
\hline Nitrate plus nitrite nitrogen & 81 & Yes & -.18 & -9.9 \\
\hline Phosphorus & 81 & Yes & -.013 & -6.9 \\
\hline \multicolumn{5}{|c|}{04229500 Honeoye Creek at Honeoye Falls } \\
\hline Chloride & 94 & Yes & nd & nd \\
\hline Sulfate & 59 & Yes & -- & -- \\
\hline Ammonia plus organic nitrogen & 96 & Yes & nd & nd \\
\hline Nitrate plus nitrite nitrogen & 96 & Yes & -.03 & -10 \\
\hline Phosphorus & 96 & Yes & nd & nd \\
\hline \multicolumn{5}{|c|}{04230500 Oatka Creek at Garbutt } \\
\hline Chloride & 94 & Yes & nd & nd \\
\hline Sulfate & 62 & nd & -- & -- \\
\hline Ammonia plus organic nitrogen & 97 & Yes & nd & nd \\
\hline Nitrate plus nitrite nitrogen & 97 & Yes & -.06 & -3.0 \\
\hline Phosphorus & 97 & Yes & -.010 & -9.8 \\
\hline \multicolumn{5}{|c|}{04231000 Black Creek at Churchville } \\
\hline Chloride & 77 & Yes & nd & nd \\
\hline Sulfate & 48 & Yes & -- & -- \\
\hline Ammonia plus organic nitrogen & 78 & Yes & nd & nd \\
\hline Nitrate plus nitrite nitrogen & 78 & Yes & -.13 & -9.1 \\
\hline Phosphorus & 78 & Yes & nd & nd \\
\hline \multicolumn{5}{|c|}{04232034 Irondequoit Creek at Railroad Mills, near Fishers } \\
\hline Chloride & 77 & Yes & nd & nd \\
\hline Sulfate & 36 & Yes & -- & -- \\
\hline Ammonia plus organic nitrogen & 80 & Yes & -.05 & -7.0 \\
\hline Nitrate plus nitrite nitrogen & 80 & Yes & nd & nd \\
\hline Phosphorus & 80 & Yes & nd & nd \\
\hline \multicolumn{5}{|c|}{04232050 Allen Creek near Rochester } \\
\hline Chloride & 86 & Yes & nd & nd \\
\hline Sulfate & 41 & nd & -- & -- \\
\hline Ammonia plus organic nitrogen & 89 & Yes & nd & nd \\
\hline Nitrate plus nitrite nitrogen & 89 & Yes & -.07 & -7.7 \\
\hline Phosphorus & 89 & Yes & nd & nd \\
\hline
\end{tabular}


Table 6. Trends in concentrations of selected constituents at nine monitoring sites in Monroe County, N.Y., water years 2003-08.-Continued

[Site locations are shown in figure 1. $\mathrm{mg} / \mathrm{L}$, milligrams per liter; $\mathrm{nd}$, trend not detected; --, insufficient data for trend analysis; $\mathrm{p}$, probability that trend is not statistically significant]

\begin{tabular}{|c|c|c|c|c|}
\hline \multirow{2}{*}{ Constituent } & \multirow{2}{*}{$\begin{array}{c}\text { Number of } \\
\text { samples }\end{array}$} & \multirow{2}{*}{ Seasonal trend ${ }^{1}$} & \multicolumn{2}{|c|}{ Monotonic trend in concentration ${ }^{2}$} \\
\hline & & & (mg/L per year) & (percent per year) \\
\hline \multicolumn{5}{|c|}{0423205010 Irondequoit Creek above Blossom Road, Rochester } \\
\hline Chloride & 141 & Yes & nd & nd \\
\hline Sulfate & 84 & Yes & -- & -- \\
\hline Ammonia plus organic nitrogen & 146 & Yes & -.04 & -5.3 \\
\hline Nitrate plus nitrite nitrogen & 146 & Yes & -.06 & -5.9 \\
\hline Phosphorus & 146 & Yes & -.008 & -6.1 \\
\hline \multicolumn{5}{|c|}{0423205025 Irondequoit Creek at Empire Boulevard, Rochester } \\
\hline Chloride & 142 & Yes & nd & nd \\
\hline Sulfate & 85 & Yes & -- & -- \\
\hline Ammonia plus organic nitrogen & 147 & Yes & -.09 & -11 \\
\hline Nitrate plus nitrite nitrogen & 147 & Yes & -.09 & -9.8 \\
\hline Phosphorus & 147 & Yes & -.020 & -14 \\
\hline \multicolumn{5}{|c|}{431510077363501 Genesee River at Charlotte Pump Station near Rochester } \\
\hline Chloride & 300 & Yes & nd & nd \\
\hline Sulfate & 0 & -- & -- & -- \\
\hline Ammonia plus organic nitrogen & 303 & Yes & -.02 & -3.2 \\
\hline Nitrate plus nitrite nitrogen & 301 & Yes & -.05 & -4.8 \\
\hline Phosphorus & 303 & Yes & +.011 & +5.7 \\
\hline
\end{tabular}

${ }^{1}$ Seasonal trends determined through annual Fourier function described by Schertz and others (1991); $p$ less than or equal to 0.05.

${ }^{2}$ Monotonic trends estimated from concentrations adjusted for flow and seasonal effects through the adjusted maximum likelihood estimation method described by Schertz and others (1991) and trend rate methods of Sen (1968); positive sign indicates increasing concentration; negative sign indicates decreasing concentration; $p$ less than or equal to 0.05 . 

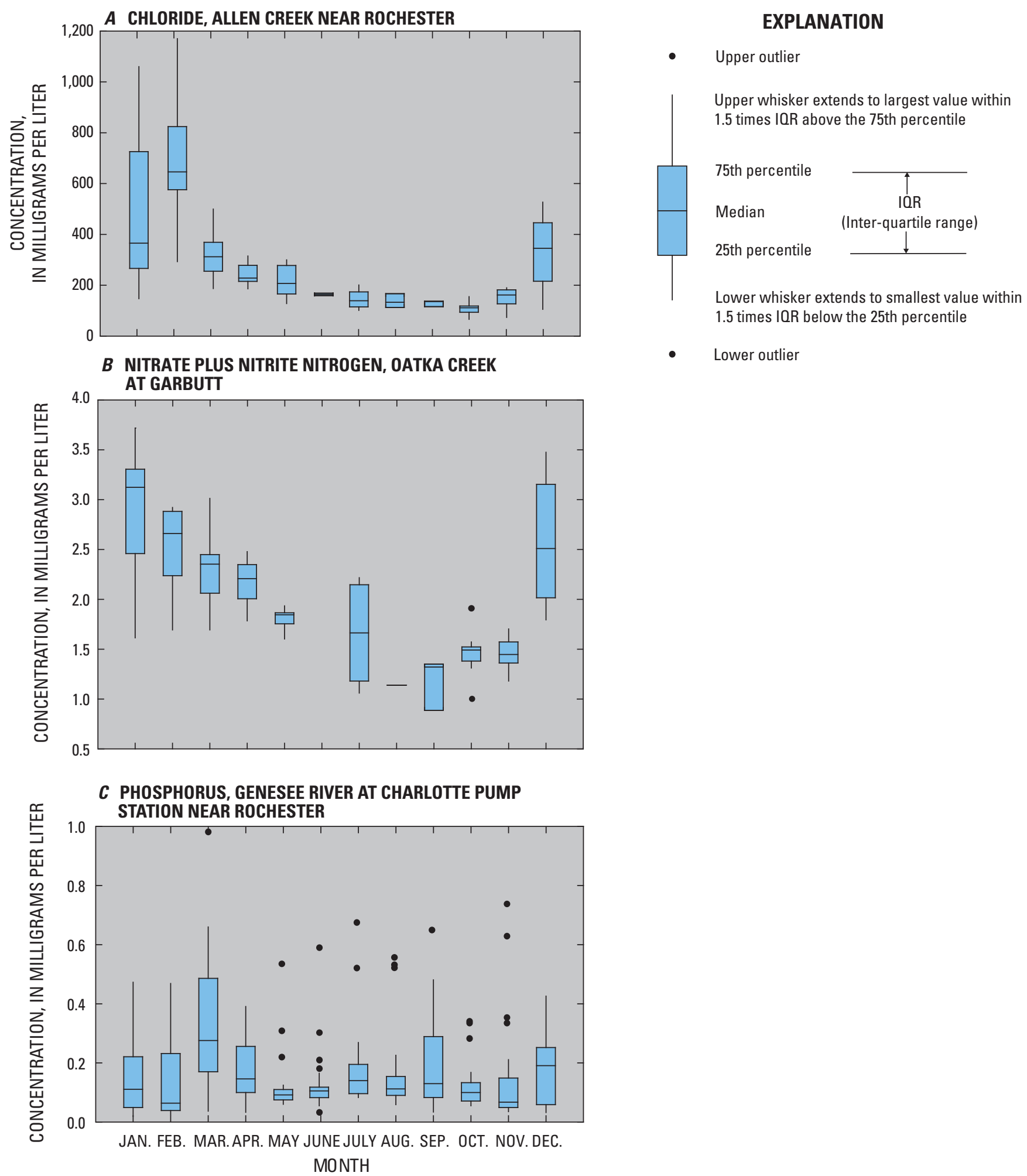

Figure 8. Seasonal variation in constituent concentration at selected sites in Monroe County, N.Y., water years 2003-08: $A$, chloride, Allen Creek near Rochester; $B$, nitrate plus nitrite nitrogen, 0 atka Creek at Garbutt; and $C$, phosphorus, Genesee River at Charlotte Pump Station near Rochester. 

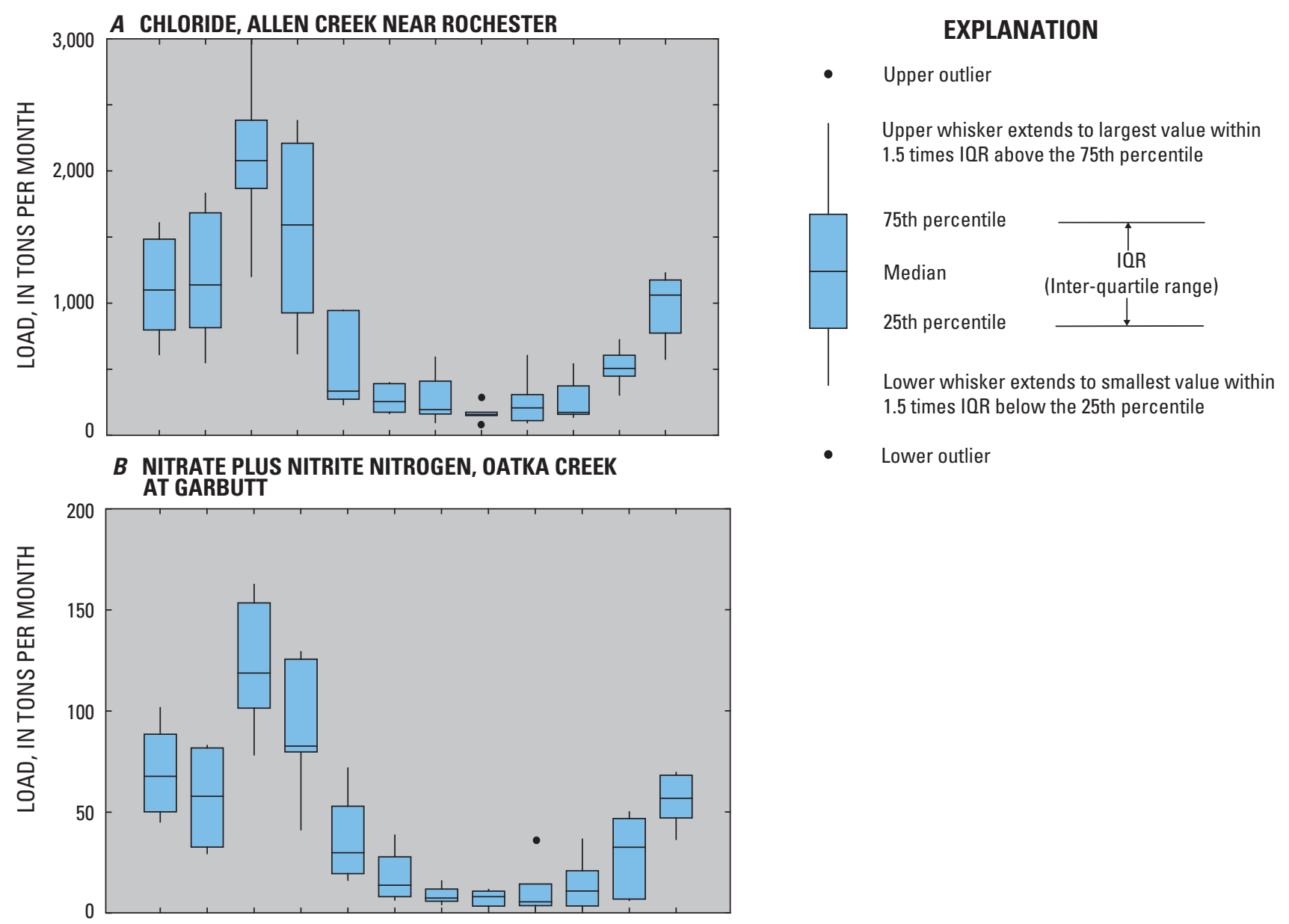

C PHOSPHORUS, GENESEE RIVER AT CHARLOTTE PUMP STATION NEAR ROCHESTER

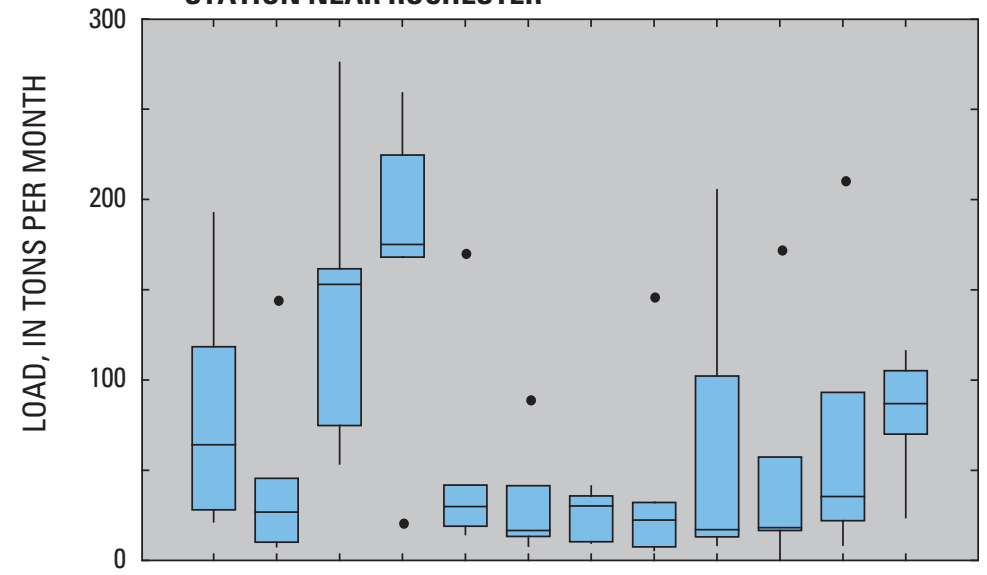

JAN. FEB. MAR. APR. MAY JUNE JULYAUG. SEP. OCT. NOV. DEC.

MONTH

Figure 9. Seasonal variation in monthly constituent loads at selected sites in Monroe County, N.Y., water years 2003-08: $A$, chloride, Allen Creek near Rochester; $B$, nitrate plus nitrite nitrogen, Oatka Creek at Garbutt; and $C$, phosphorus, Genesee River at Charlotte Pump Station near Rochester. 


\section{Summary}

This report, the sixth in a series of analyses of the hydrologic data collected in Monroe County since 1984, presents interpretations of flow and water-quality data at nine monitoring sites for the period from October 2002 through September 2008. Monroe County encompasses $673 \mathrm{mi}^{2}$ of mixed land uses (agricultural and residential) and land covers (forests and wetlands) in northwestern New York. Although the population within Monroe County has remained fairly constant during the past 39 years (1970-2008), realignment of the population has occurred as people have moved from the city of Rochester to the developing towns that border the city. In response to this shift in population, the percentages of forested and agricultural lands have decreased, whereas those of developed land uses have increased.

Streamflow and water quality were monitored at nine sites jointly operated by the Monroe County Department of Health and the U.S. Geological Survey. The smallest basin in the monitoring network, Northrup Creek, had the highest streamflow yields (flow per unit area) due to sustained yearround discharges from the Spencerport wastewater-treatment plant and seasonal releases from the NYS Erie (Barge) Canal. Genesee River streamflow yields also were high due, in part, to the relatively high yields from the upper part of the Genesee River Basin. The lowest streamflow yields were measured in Honeoye Creek, which reflects a decrease in flows due to withdrawals from Hemlock Lake and Canadice Lake for the city of Rochester water supply.

Water samples from the nine monitoring sites were analyzed for nutrients, chloride, sulfate, and total suspended solids. The loads of constituents were computed from the concentration data and the daily flows recorded at each of the monitoring sites (where concentration data permitted). Evaluation of the loads indicated that all constituents at all sites were positively correlated with streamflow, except phosphorus at Northrup Creek and Oatka Creek, and nitrate plus nitrite nitrogen at Honeoye Creek. At these three sites, insufficient data precluded estimation of loads with regression models.

Annual constituent yields (loads per unit area) were computed to assess the relative contributions, and permit direct comparison, of loads among the study basins. All urban sitesAllen Creek and the two downstream sites on Irondequoit Creek - had seasonally high chloride concentrations and high annual yields of chloride (160 to 350 ton $/ \mathrm{mi}^{2}$ ). Chloride concentrations and yields, which increased with an increase in population and road density, were attributed to the application of road-deicing salts. The less-urbanized sites in the studyGenesee River, Honeoye Creek, Oatka Creek, and Black Creek-had relatively low concentrations and yields of chloride (30 to 86 ton $/ \mathrm{mi}^{2}$ ). The highest concentrations and yields of sulfate were measured in Black Creek, Oatka Creek, and Irondequoit Creek at Railroad Mills (120 to 210 ton/ $\mathrm{mi}^{2}$ ). These high concentrations and yields were attributed to dissolution of sulfate from gypsum (calcium sulfate) deposits in Silurian shale bedrock that crops out upstream from these monitoring sites. The Honeoye Creek monitoring site lies south (upstream) of the gypsum-bearing outcrops; hence, sulfate concentrations and yields at this site (17 to $32 \mathrm{ton} / \mathrm{mi}^{2}$ ) did not reflect this source. Sulfate in the urban streams, which generally lie north of the gypsum-bearing outcrops, was attributed to this bedrock source, as well as to atmospheric deposition from industrial and transportation sources.

Samples from Northrup Creek had the highest concentrations of phosphorus, orthophosphate, and nitrogen, and high yields of nitrate plus nitrite nitrogen (1.8 to $3.4 \mathrm{ton} / \mathrm{mi}^{2}$ ) and ammonia plus organic nitrogen (1.2 to $2.5 \mathrm{ton} / \mathrm{mi}^{2}$ ). These results were attributed to a combination of sources, including discharges from the village of Spencerport wastewater-treatment plant (which ceased operation in June 2008), diversions from the NYS Erie (Barge) Canal, and manure and fertilizers applied to agricultural fields. Concentrations and yields of nitrate plus nitrite nitrogen were also high in Oatka Creek and Black Creek (1.8 to 3.2 ton $/ \mathrm{mi}^{2}$ ), which drain substantial areas in agricultural use. Allen Creek had the second highest yields of ammonia plus organic nitrogen ( 0.76 to 2.0 ton/ $\left.\mathrm{mi}^{2}\right)$. Honeoye Creek, which drains the relatively undeveloped source areas of drinking water for the city of Rochester-Hemlock and Canadice Lakes - had the lowest yields of nitrate plus nitrite nitrogen and ammonia plus organic nitrogen. The second highest median concentrations and highest sample concentrations of phosphorus and orthophosphate were measured in samples from the Genesee River. This stream also had the highest phosphorus yields ( 0.24 to $0.51 \mathrm{ton} / \mathrm{mi}^{2}$ ), which presumably were associated with nutrient and sediment transport from agricultural areas in the basin and from streambank erosion.

A comparison of the yields computed for the two downstream sites on Irondequoit Creek - at Blossom Road and Empire Boulevard - permitted an assessment of the mitigative effects of the Ellison Park wetland on constituent loads, which otherwise would have been transported to Irondequoit Bay. These effects were enhanced by a flow-control structure (installed mid-way through the wetland during February 1997), which was designed to increase the dispersal and shortterm detention of stormflows in the wetland. The wetland significantly decreased yields of particulate constituentsphosphorus and ammonia plus organic nitrogen — but had little effect on the yields of dissolved constituents - chloride, sulfate, and nitrate plus nitrite nitrogen.

Trends in flow-adjusted concentrations were identified at all sites for five of the nutrient constituents that were evaluated - chloride, sulfate, ammonia plus organic nitrogen, nitrate plus nitrite nitrogen, and phosphorus. All of the monotonic time trends indicated that nutrient concentrations decreased during the 6-year study, except for phosphorus concentrations at the Genesee River monitoring site, which increased. Seasonal trends in concentrations also were identified at all sites for nearly every constituent that was evaluated. The effect of applications of road salt to paved 
areas throughout the study area during winter months was increased chloride concentrations from December through February; chloride loads were four to eight times higher in runoff during winter and early spring than during summer months. The concentrations and loads of nitrate plus nitrite nitrogen also were generally greatest during the late fall through the early spring months, when fertilizers and manure that had been applied to residential lawns or fallow farm fields were transported to streams by snowmelt and spring rains and when denitrification by bacterial action was minimal. During summer months, nitrate plus nitrite nitrogen loads were minimal because of low flows, limited nitrogen applications on growing crops, and active denitrification processes. The monthly pattern of concentrations and loads of phosphorus differed slightly from that of nitrate plus nitrite nitrogen, in part because phosphorus is affected more by runoff processes that control solid-phase particulate transport, whereas nitrate is transported largely in a dissolved phase.

\section{References Cited}

American Public Health Association, American Water Works Association, and Water Environment Federation, 2010, Standard methods for examination of water and wastewater: American Public Health Association, accessed January 19, 2010, at http://www.standardmethods.org/.

Broughton, J.G., Fisher, D.W., Isachsen, Y.W., Rickard, L.V., and Offield, T.W., 1962, The geology of New York State: Albany, New York State Museum-Geological Survey, Map and Chart Series no. 5, 5 sheets, scale 1:250,000.

Bubeck, R.C., and Burton, R.S., 1989, Changes in chloride concentrations, mixing patterns, and stratification characteristics of Irondequoit Bay, Monroe County, New York, after decreased use of road-deicing salts, 1974-84: U.S. Geological Survey Water-Resources Investigation Report 87-4223, $52 \mathrm{p}$.

Buchanan, T.J., and Somers, W.P., 1968, Stage measurement at gaging stations: U.S. Geological Survey Techniques of Water-Resources Investigations, book 3, chap. A7, 28 p.

Buchanan, T.J., and Somers, W.P., 1969, Discharge measurements at gaging stations: U.S. Geological Survey Techniques of Water-Resources Investigations, book 3, chap. A8, 65 p.

Carter, R.W., and Davidian, Jacob, 1968, General procedure for gaging streams: U.S. Geological Survey Techniques of Water-Resources Investigations, book 3, chap. A6, 13 p.
Cohn, T. A., Caulder, D. L., Gilroy, E. J., Zynjuk, L. D., and Summers, R. M., 1992, The validity of a simple statistical model for estimating fluvial constituent loads - an empirical study involving nutrient loads entering Chesapeake Bay: Water Resources Research, v. 28, no. 9, p. 2353-2363.

Coon, W.F., 1997, Hydrology, sedimentology, and biology of Ellison Park wetland at the mouth of Irondequoit Creek near Rochester, New York: U.S. Geological Survey WaterResources Investigations Report 96-4269, 41 p.

Coon, W.F., 2004, Effects of flow modification on a cattail wetland at mouth of Irondequoit Creek near Rochester, New York - water levels, wetland biota, sediment, and water quality: U.S. Geological Survey Water-Resources Investigations Report 03-4224, 90 p.

Coon, W.F., 2008, Hydrologic evidence of climate change in Monroe County, New York: U.S. Geological Survey OpenFile Report 2008-1199, 12 p., also available at http://pubs. usgs.gov/of/2008/1199/.

Coon, W.F., Bernard, J.M, and Seischab, F.K., 2000, Effects of a cattail wetland on water quality of Irondequoit Creek near Rochester, New York: U.S. Geological Survey WaterResources Investigations Report 00-4032, 74 p.

Elliott, J.M., 1981, Some aspects of thermal stress on freshwater teleosts, in Pickering, A.D., ed., Stress and fish: London, Academic Press, p. 209245

Genesee County, 2009, Unique geological features of Genesee County, accessed December 7, 2009, at http://www. co.genesee.ny.us/dpt/soilandwater/powerpt4.html.

Gilbert, B.K., and Kammerer, J.C., 1971, Hydrology of the Genesee River Basin, New York and Pennsylvania: U.S. Geological Survey Hydrologic Investigations Atlas HA-368, 4 sheets.

Gray, J.R., Glysson, G.D., Turcios, L.M., and Schwarz, G.E., 2000, Comparability of suspended-sediment concentration and total suspended solids data: U.S. Geological Survey Water-Resources Investigations Report 00-4191, 14 p.

Hirsch, R.M., Slack, J.R., and Smith, R.A., 1982, Techniques of trend analysis for monthly water quality data: Water Resources Research, v. 18, no. 1, p. 107-121.

Homer, C., Huang, C., Yang, L., Wylie, B., and Coan, M., 2004, Development of a 2001 national land-cover database for the United States: Photogrammetric Engineering and Remote Sensing, v. 70, no. 7, p. 829-840, also available at http://www.mrlc.gov/pdf/July_PERS.pdf. (National Land Cover Data available for downloading at http://www.mrlc. gov, accessed January 19, 2010) 
Johnston, W.H., and Sherwood, D.A., 1996, Water resources of Monroe County, New York, water years 1984-88, with emphasis on water quality in the Irondequoit Creek Basin, Part 2-atmospheric deposition, ground water, streamflow, trends in water quality, and chemical loads to Irondequoit Bay: U.S. Geological Survey Water-Resources Investigations Report 96-4054, 84 p.

Kappel, W.M., Yager, R.M., and Zarriello, P.J., 1986, Quantity and quality of urban storm runoff in the Irondequoit Creek Basin near Rochester, New York, Part 2-Quality of storm runoff and atmospheric deposition, rainfall-runoff-quality modeling, and potential of wetlands for sediment and nutrient retention: U.S. Geological Survey Water-Resources Investigations Report 85-4113, 93 p.

Kennedy, E.J., 1983, Computation of continuous records of streamflow: U.S. Geological Survey Techniques of WaterResources Investigations, book 3, chap. A13, 53 p.

Monroe County Water Quality Planning Bureau, 2001, The effects of road salt on water quality in Monroe County: Monroe County Water Quality Planning Bureau, 15 p.

National Climatic Data Center, 2009a, Climatography of the United States, No. 20, 1971-2000, Rochester Monroe County Airport, NY: National Climatic Data Center, accessed November 20, 2009,http://cdo.ncdc.noaa.gov/ climatenormals/clim20/ny/307167.pdf.

National Climatic Data Center, 2009b, Rochester Greater International Airport-About this station: National Climatic Data Center, accessed November 20, 2009, at http://www4.ncdc.noaa.gov/cgi-win/wwcgi.dll?wwDI $\sim \operatorname{StnS}$ rch $\sim \operatorname{StnID~20020006.~}$

National Climatic Data Center, 2009c, National Oceanic and Atmospheric Administration, Satellite and Information Service: National Climatic Data Center, accessed November 20, 2009, at http://www.ncdc.noaa.gov/oa/mpp/ freedata.html.

New York State Department of Environmental Conservation, 1991, Water quality regulation of surface water and ground water, 6NYCRR Parts 700-705: Albany, N.Y.

New York State Department of Environmental Conservation, 2003, The 2001 Genesee River Basin waterbody inventory and priority waterbodies list: New York State Department of Environmental Conservation, 139 p., accessed January 20, 2010, at http://www.dec.ny.gov/docs/water_pdf/ pwlgenes03.pdf.

New York State Office of Real Property Services, 2009, Property classification codes: accessed November 24, 2009, at http://www.orps.state.ny.us/assessor/manuals/vol6/ref/ prclas.htm.
O'Brien and Gere, 1983, Nationwide urban runoff program, Irondequoit Basin study, final report: Rochester, N.Y., Irondequoit Bay Pure Waters District, 164 p.

Randall, A.D., 1996, Mean annual runoff, precipitation, and evapotranspiration in the glaciated northeastern United States, 1951-80: U.S. Geological Survey Open-File Report 96-395, 2 plates.

Rantz, S.E., and others, 1982, Measurement and computation of streamflow-volumes 1 and 2: U.S. Geological Survey Water-Supply Paper 2175, $631 \mathrm{p}$.

Runkel, R.L., Crawford, C.G., and Cohn, T.A., 2004, Load estimator (LOADEST) - A FORTRAN program for estimating constituent loads in streams and rivers: U.S. Geological Survey Techniques and Methods, book 4, chap. A5, 69 p. Also available online at http://pubs.usgs. gov/tm/2005/tm4A5/.

Schertz, T.L., Alexander, R.B., and Ohe, D.J., 1991, The computer program Estimate Trend (ESTREND), a system for the detection of trends in water-quality data: U.S. Geological Survey Water-Resources Investigations Report 91-4040, $63 \mathrm{p}$.

Sen, P.K., 1968, Estimates of regression coefficient based on Kendall's tau: Journal of the American Statistical Association, v. 63, p. 1379-1389.

Sherwood, D.A., 1999, Water resources of Monroe County, New York, water years 1989-93, with emphasis on water quality in the Irondequoit Creek Basin, Part 2-atmospheric deposition, ground water, streamflow, trends in water quality, and chemical loads to Irondequoit Bay: U.S. Geological Survey Water-Resources Investigations Report 99-4084, $50 \mathrm{p}$.

Sherwood, D.A., 2001, Water resources of Monroe County New York, water years 1994-96, with emphasis on water quality in the Irondequoit Creek Basin—atmospheric deposition, ground water, streamflow, trends in water quality, and chemical loads to Irondequoit Bay: U.S. Geological Survey Water-Resources Investigations Report 00-4201, 44 p.

Sherwood, D.A., 2003, Water resources of Monroe County, New York, water years 1997-99, with emphasis on water quality in the Irondequoit Creek Basin-atmospheric deposition, ground water, streamflow, trends in water quality, and chemical loads to Irondequoit Bay: U.S. Geological Survey Water-Resources Investigations Report 02-4221, $55 \mathrm{p}$. 
Sherwood, D.A., 2005, Water resources of Monroe County, New York, water years 200002 - atmospheric deposition, ground water, streamflow, trends in water quality, and chemical loads in streams: U.S. Geological Survey Scientific Investigations Report 2005-5107, 55 p.

Somerfield, Mark, 2010, Urban heat island causes—why cities are warmer than rural areas: Suite101.com, accessed April 30, 2010 at http://climatology.suite101.com/article.cfm/ urban-heat-island-causes-why-cities-are-warmer-than-ruralareas.

U.S. Census Bureau, 2009a, American factfinder: U.S. Census Bureau, accessed December 2, 2009, at http://factfinder. census.gov/.

U.S. Census Bureau, 2009b, County Population Census Counts 1900-90: U.S. Census Bureau, accessed November 16, 2009, at http://www.census.gov/population/www/ censusdata/cencounts/index.html.

U.S. Environmental Protection Agency, 1983, Results of the Nationwide Urban Runoff Program - Executive summary: U.S. Environmental Protection Agency Water Planning Division WH-554, 24 p.

U.S. Geological Survey, 2009a, National water information system, USGS water data for the nation: U.S. Geological Survey, accessed May 11, 2009, at http://waterdata.usgs. gov/nwis/.

U.S. Geological Survey, 2009b Annual water data reports: U.S. Geological Survey, accessed May 12, 2009, at http://wdr.water.usgs.gov/.
U.S. Geological Survey, 2009c, Standard reference sample program: U.S. Geological Survey Branch of Quality Systems, accessed October 6, 2009, at http://bqs.usgs.gov/ srs/.

Young, R.A., 1993, Analysis and recommendations for ground-water sampling program (1988-93), Irondequoit Creek Basin, with emphasis on the Ellison Park-Browncroft Boulevard reach: Rochester, N.Y., Monroe County Health Department, unpublished report, $20 \mathrm{p}$.

Zarriello, P.J., 1996, Simulated effects of a stormwaterdetention basin on peak flows and water quality of East Branch Allen Creek, Monroe County, New York: U.S. Geological Survey Water-Resources Investigations Report 95-4157, $34 \mathrm{p}$.

Zarriello, P.J., Harding, W.E., Yager, R.M., and Kappel, W.M., 1985, Quantity and quality of storm runoff in the Irondequoit Creek Basin near Rochester, New York, Part 1-Data-collection network and methods, quality-assurance program, and description of available data: U.S. Geological Survey Open-File Report 84-610, 44 p.

Zarriello, P.J., and Sherwood, D.A., 1993, Effects of stormwater detention on the chemical quality of runoff from a small residential development, Monroe County, New York: U.S. Geological Survey Water-Resources Investigations Report 92-4003, 57 p.

Zarriello, P.J., and Surface, J.M., 1989, Simulation of changes in stormwater quality at four potential flow-attenuation sites in the Irondequoit Creek watershed, Monroe County, New York: U.S. Geological Survey Water-Resources Investigations Report 88-4106, 52 p. 
Prepared by the Pembroke Publishing Service Center

For additional information write to:

New York Water Science Center

U.S. Geological Survey

30 Brown Rd.

Ithaca, NY 14850

Information requests:

(518) 285-5602

or visit our Web site at: http://ny.water.usgs.gov 
